\title{
Inflation Risk in Corporate Bonds
}

\author{
Johnny Kang, Carolin E. Pflueger
}

First draft: November 2011

This version: December 2012

\begin{abstract}
We argue that corporate bond yields reflect fear of debt deflation. Most bonds are nominal, so unexpectedly low inflation raises firms' real leverage and increases defaults. In a real business cycle model with time-varying inflation risk and optimal but infrequent capital structure, more volatile or pro-cyclical inflation leads to quantitatively important increases in corporate - default free yield spreads. Consistent with model predictions, we find in a panel of six developed countries that credit spreads increase by 14 basis points if either inflation volatility or the inflation-stock correlation increases by one standard deviation.
\end{abstract}

Kang: Harvard Business School, Boston MA 02163. hjkang@hbs.edu. Pflueger: University of British Columbia, Vancouver BC V6T 1Z2, Canada. carolin.pflueger@sauder.ubc.ca. We are grateful to an anonymous referee, Shai Bernstein, Josh Coval, Ben Friedman, Josh Gottlieb, Francois Gourio, Robin Greenwood, Robert Hall, Sam Hanson, Stephanie Hurder, Jakub Jurek, Jacob Leshno, Robert Merton, Nick Roussanov, Alp Simsek, Jeremy Stein, Jim Stock, Adi Sunderam, seminar participants at the University of British Columbia, Brown University, the Federal Reserve Board, the Federal Reserve Bank of Chicago, Harvard University, the University of Illinois at Urbana-Champaign, London Business School, the University of Michigan, the University of Rochester, Washington University in St. Louis, the University of Wisconsin-Madison, and the Yale School of Management for helpful comments and suggestions. We are especially grateful to John Campbell, Erik Stafford, and Luis Viceira for invaluable advice and guidance. 
Bonds in the developed world overwhelmingly carry fixed nominal face values, so real values fluctuate with inflation. When corporate debt is nominal, firms can be driven into default by either a decrease in real cash flows or an increase in real liabilities. The literature has argued that the volatility of real firm values is priced into corporate bond spreads. We find that inflation risk plays at least as large a role in explaining variation in the spread between corporate bond yields and default-free bond yields.

Inflation cyclicality - as proxied by the inflation-stock correlation - peaked during the financial crisis, when inflation dropped to extremely low levels. Our results therefore indicate that concerns about debt deflation (Fisher (1933)) and potentially important macroeconomic feedback effects (Bernanke and Gertler (1989), Kiyotaki and Moore (1997)) are of renewed relevance today.

Inflation risk can increase credit spreads in two ways. First, more volatile inflation increases the ex ante probability that firms will default due to high real liabilities. Second, when inflation and real cash flows are highly correlated, low real cash flows and high real liabilities tend to hit firms at the same time, increasing default rates and real investor losses. In this second case, higher credit spreads reflect higher expected credit losses and a higher risk premium due to the greater concentration of defaults in high marginal utility states.

There has been a close historical relationship between firms' cost of debt finance and inflation uncertainty in the United States, as shown in Figure 1 1 B Both inflation uncertainty and credit spreads were high during the 1980s and 1980s, but they decreased substantially towards the 1990s. Our empirical results confirm the relationship between credit spreads and inflation uncertainty in a panel of six developed countries, controlling for proxies for business conditions, real uncertainty

\footnotetext{
${ }^{1}$ Figure 1 shows the Moody's Baa over Aaa credit spread. The Survey of Professional Forecasters provides forecasters' average survey probabilities that the annual-average over annual-average GDP index inflation falls into a particular range. Panel A shows the smoothed difference between the 90th and the 10th inflation distribution percentiles and Panel B shows the smoothed difference between the 50th and the 10th percentiles. The 10th percentile is treated as missing if the lowest survey inflation range receives a probability of greater than $15 \%$.
} 
and time-varying risk aversion.

The key driver of real firm liabilities is the level of inflation relative to expectations, so debt deflation can be relevant even when inflation is high. It might seem counterintuitive that there were concerns about lower than expected inflation during the 1970s and 1980s. However, during high inflation periods uncertainty about the central banks' willingness to control inflation can generate uncertainty about whether and when inflation will fall substantially (Ball (1992)).

Panel B shows that the close relation between inflation uncertainty and the credits spread is indeed driven by the left tail of the inflation distribution. This finding is consistent with our proposed mechanism, where lower than expected inflation increases credit risk, but higher than expected inflation does not.

We formally derive new, testable implications of the impact of time-varying inflation risk on credit spreads in a model with stochastic productivity and optimal but infrequent capital structure choice. In simulated data, inflation risk explains a substantial fraction of the variation in credit spreads, controlling for real uncertainty. Simulated credit spreads increase by 27 basis points (bps) if the annualized standard deviation of inflation shocks increases by 1 percentage point and by 20 bps if the inflation-stock return correlation increases by 100 percentage points.

Three key features in our model generate large, dynamic responses of credit spreads to inflation risk. First, we model both the size of inflation shocks and their correlation with real outcomes as varying over time independently of real activity.

Second, we assume that firms issue nominal long-term bonds and that expected inflation is persistent, consistent with U.S. and international evidence (Ball and Cecchetti (1990), Stock and Watson (2007)). We think of the assumption of nominal bonds as reasonable for developed countries, where bonds are denoted in nominal terms by historical convention. In an equilibrium, where bonds are denoted in nominal terms, the first issuance of inflation-indexed corporate debt plausibly 
carries a substantial liquidity premium. In our calibrated model, a liquidity premium comparable to that documented for U.S. inflation-indexed government bonds (Pflueger and Viceira (2011)) prevents firms from switching to inflation-indexed bonds.

The combination of long-term nominal bonds and persistent inflation implies that small permanent shocks to inflation can have large effects on real liabilities. For instance, a permanent decrease in log inflation from three to one percent per annum (p.a.) increases the expected real principal repayment on a 10 year nominal bond by 22 percent. A drop in the real interest rate also increases credit risk, but it does so because it reflects expected real growth and risk premia in the real economy. In our real business cycle model, the real interest rate is fully captured by lagged stock returns, equity volatility, and the dividend-price ratio. On the other hand, surprise inflation matters for credit spreads above and beyond these variables.

Third, firms in our model refinance infrequently. This assumption is empirically well-founded and helps generate a realistic level of credit spreads. When firms can adjust leverage, they choose optimally following a textbook tradeoff theory (Gourio (2011)). When inflation risk raises the cost of debt finance, young firms in our overlapping generations model reduce leverage. However, old firms' inability to respond magnifies the increase in credit spreads.

We provide new evidence that corporate bond investors price the risk of debt deflation in a panel of corporate bond spread indices from Australia, Canada, Germany, Japan, the United Kingdom, and the United States over four decades. In a pooled regression, one standard deviation increases in inflation volatility or in the inflation-stock correlation are associated with spread increases of $14 \mathrm{bps}$ and $16 \mathrm{bps}$, respectively. These movements are large relative to average credit spreads of $100 \mathrm{bps}$. We find that inflation risk is priced into credit spreads even in developed countries with moderate inflation environments. In emerging markets with more volatile inflation, inflation risk should plausibly be even more important for credit risk. 
Our proxies for inflation risk explain as much variation in credit spreads as do equity volatility and the dividend-price ratio, our proxies for real uncertainty and risk aversion. The empirical impact of inflation risk is especially large when real stock returns are low or when inflation shocks are low.

Using U.S. time series data, we provide evidence that the inflation volatility largely captures an increase in expected defaults, while the inflation-stock correlation also increases the default component in credit spreads. For the U.S. we find that inflation volatility forecasts corporate defaults over the next two to five years with similar magnitudes to the inflation volatility effect on credit spreads. The inflation-stock correlation forecasts corporate bond excess returns over the next one to four quarters, but the relation between the inflation-stock correlation and future defaults is weaker.

Stagflation has been a major fear of central bankers and investors over the past forty years. However, a new concern has emerged over the past decade: the danger of a deflationary collapse in aggregate demand (Bernanke (2002)). If investors fear that policymakers will not be able to counteract deflation should there be another recession, they will perceive inflation to be highly cyclical. Indeed, our proxy for inflation cyclicality - the inflation-stock correlation - peaked during the financial crisis, when inflation reached extremely low levels. Our estimates as of December 2010 suggest that the currently high inflation-stock correlation contributes 39 bps to the Baa-Aaa long-term Moody's U.S. credit spread.

The remainder of the paper is organized as follows. After a brief literature review, Section 1 introduces the model. We derive firms' optimal default behavior as a function of leverage, real shocks and inflation shocks. Section $\Pi$ argues that inflation risk should be quantitatively important for credit spreads in a calibrated version of the model. Section III tests the empirical predictions from the model in an international panel of credit spread indices, and Section $\mathrm{IV}$ concludes. 


\section{A. Literature Review}

This paper builds naturally on Campbell, Sunderam, and Viceira (2011) and Pflueger and Viceira (2011) who show that inflation risk is priced into default free government bonds. Time variation in inflation volatility was first modeled by Engle (1982). There is also substantial bond market evidence of time-varying inflation cyclicality (Li (2002), Baele, Bekaert, and Inghelbrecht (2009), David and Veronesi (2009), Viceira (2010), Wright (2010), Campbell, Sunderam, and Viceira (2011)).

This paper also speaks to a large literature on the empirical determinants of corporate bond spreads by showing that inflation risk can help explain variation in credit spreads in addition to aggregate and idiosyncratic equity volatility (Collin-Dufresne, Goldstein, and Martin (2001), Campbell and Taksler (2003)). Ferson and Harvey (1991) used government bond, corporate bond, and stock portfolio returns to estimate the risk premium for exposure to inflation surprises. We add to their analysis by arguing that the time-varying second moments of inflation surprises are priced into corporate bonds.

We add to previous structural models of credit risk such as Merton (1974), and Longstaff and Schwartz (1995) by allowing the risk of inflation to vary over time. We also contribute to the wide literature on asset pricing models with optimal leverage and default by arguing that firms should adjust their capital structure in response to time-varying inflation risk (Leland and Toft (1996), Goldstein, Ju, and Leland (2001), Hackbarth, Miao, and Morellec (2006), Chen, Collin-Dufresne, and Goldstein (2009), Bhamra, Kuehn, and Strebulaev (2010a), Bhamra, Kuehn, and Strebulaev (2010b), Gomes and Schmid (2010), Gourio (2011)). Our model of firms' optimal capital structure has analogies to households' optimal mortgage choice under inflation risk (Campbell and Cocco (2003), Koijen, van Hemert, and van Nieuwerburgh (2009)) but it differs in that all assets are priced by the same representative investor. 
This paper is closely related to recent models of monetary policy when firms' liabilities are nominal (Bhamra, Fisher, and Kuehn (2011), De Fiore and Tristani (2011)). Our model highlights inflation volatility and inflation cyclicality as driving credit risk and has directly testable predictions. Transition dynamics in our model increase the quantitative impact of inflation risk on credit spreads.

\section{A Dynamic Model of Inflation Risk in Corporate Bonds}

Our model relies on a standard production function and standard trade-off theory of capital structure, as in the corporate bond pricing framework of Gourio (2011). We depart from standard practice by assuming that corporate debt is long-term and nominal and by assuming that the second moments of inflation are time-varying. Our assumption of overlapping generations of firms is also nonstandard. This modeling tool allows us to capture infrequent debt refinancing in a tractable manner.

\section{A. Intuition: Contingent Claim Payoff Profiles}

Figure 2 illustrates the key theoretical predictions using real payoff profiles of nominal default-free and corporate bonds. Black and Scholes (1973) and Merton (1974) show that owning a corporate bond is equivalent to owning a default-free bond and selling a put on the company's underlying assets.2

Figures $2 \mathrm{~A}$ and $2 \mathrm{~B}$ show that when inflation is more uncertain credit spreads should be higher to reflect the increased payoff gap between corporate and default-free bonds. Figure $2 \mathrm{~B}$ shows real

\footnotetext{
${ }^{2}$ For simplicity in Figure 2 both the defaultable and default-free bonds are zero coupon with a fixed and equal nominal face value. The representative firm defaults when the real asset value falls below the real face value of liabilities and in default bond holders become the residual claimants on the firm's assets.
} 
conditional expected payoffs, averaged over different inflation levels, when inflation is uncertain but uncorrelated with real assets. When inflation is uncertain the default probability is nonzero for any underlying real asset value, and hence the payoff gap increases relative to the case with no inflation uncertainty.

Comparing Figures 2C and 2D shows that when inflation is procyclical, credit spreads should be higher. In Figure 2C, inflation is high in booms, low in recessions, and perfectly correlated with real assets. In Figure 2C, firms get hit twice during recessions because they experience low real asset values and high real liabilities at the same time. The gap between default-free and corporate bonds is especially large when real asset values are low and marginal utility is high, so credit spreads should increase further to include a larger default risk premium.

\section{B. Timing of Cohort $t$}

We model overlapping generations of firms, with each firm producing for two periods. Firms cannot adjust their capital structure in the intermediate period, so leverage is sticky 3

Figure 3 illustrates the timing for a firm that enters at the end of period $t$. At the end of period $t$ the firm chooses its face value of nominal two-period debt $B_{t}^{\$}$ and purchases capital $K_{t+1}^{y}$, which will be available for production at time $t+1$. The firm's newly issued corporate bonds have two periods remaining to maturity.

In period $t+1$, aggregate productivity and inflation shocks are realized. Each firm experiences an idiosyncratic shock to its capital stock and produces. The firm is unable to adjust its capital structure. The firm's seasoned corporate bonds have one period remaining to maturity.

In period $t+2$, firms again receive shocks and produce. At the end of period $t+2$, equity

\footnotetext{
${ }^{3}$ For empirical evidence on sticky leverage see Baker and Wurgler (2002), Welch (2004) and Leary and Roberts (2005).
} 
holders decide whether to default. Equity and debt holders receive payments.

\section{Production}

Firms produce according to a standard Cobb-Douglas production function with capital and labor inputs. At time $t$, firm $i$ with capital $K_{t}^{i}$ and labor $N_{t}^{i}$ produces output $Y_{t}^{i}$ :

$$
Y_{t}^{i}=\left(z_{t} N_{t}^{i}\right)^{1-\alpha}\left(K_{t}^{i}\right)^{\alpha}
$$

Total factor productivity (TFP) $z_{t}$ is independently and identically distributed with a trend:

$$
z_{t+1}=\exp (\mu t) \exp \left(\varepsilon_{t+1}^{T F P}-\frac{1}{2} \sigma^{2}\right) \text { with } \varepsilon_{t+1}^{T F P} \stackrel{i i d}{\sim} N\left(0, \sigma^{2}\right)
$$

We calibrate one time period to equal 5 years, which is close to business cycle frequency, so independent TFP shocks are a reasonable approximation. TFP trend $\mu$ is also the equilibrium trend growth rate for output and consumption in the economy.

Firm $i$ chooses labor optimally to maximize single period operating revenue, while taking the aggregate wage as given. We assume that the aggregate supply of labor is fixed at 1, abstracting from unemployment. In equilibrium, the aggregate wage adjusts to ensure clearing of the labor market.

We define aggregate output, capital, and investment at time $t$ by integrating over all firms:

$$
Y_{t}=\int_{i} Y_{t}^{i} d i, K_{t}=\int_{i} K_{t}^{i} d i, N_{t}=\int_{i} N_{t}^{i} d i, I_{t}=\int_{i} I_{t}^{i} d i
$$

Capital depreciates at a constant rate $\delta$ and we impose the resource constraint that total output is 
equal to the sum of aggregate consumption and investment:

$$
\begin{aligned}
K_{t+1} & =I_{t}+(1-\delta) K_{t} \\
Y_{t} & =C_{t}+I_{t} .
\end{aligned}
$$

Solving for the equilibrium hiring policy, total output at time $t$ is given by $Y_{t}=z_{t}^{1-\alpha} K_{t}^{\alpha}$. Young and old firms are heterogeneous in their capital stock, but the constant returns to scale production technology implies that the return on capital from time $t$ to time $t+1$ for any firm equals:

$$
R_{t+1}^{K}=\left[\alpha\left(\frac{z_{t+1}}{K_{t+1}}\right)^{1-\alpha}+(1-\delta)\right]
$$

From (6) the expected level and the volatility of real returns on capital are endogenously higher when the capital stock $K_{t+1}$ is low relative to trend.

\section{Inflation}

The economy is subject to inflation surprises, whose relationship with productivity shocks can change over time. Let $P_{t}$ the price level at time $t$ and $\pi_{t} \log$ inflation from time $t-1$ to time $t$ :

$$
\pi_{t}=\log \left(P_{t} / P_{t-1}\right)
$$

Consistent with U.S. and international empirical evidence (e.g. Stock and Watson (2007), Ball and Cecchetti (1990)), we model expected log inflation as following a random walk. The dynamics of expected inflation resemble a backward-looking Phillips curve, consistent with empirical evidence (Fuhrer (1997)). Inflation persistence implies that uncertainty about the price level increases 
with the time horizon, so inflation risk should be larger for longer maturity bonds: $4^{4}$

$$
\begin{aligned}
\pi_{t+1} & =\pi_{t}+\varepsilon_{t+1}^{\pi}, \\
\varepsilon_{t+1}^{\pi} \mid \sigma_{t+1}^{\pi} & \sim N\left(0,\left(\sigma_{t+1}^{\pi}\right)^{2}\right), \\
\operatorname{Corr}\left(\varepsilon_{t+1}^{\pi}, \varepsilon_{t+1}^{T F P} \mid \rho_{t+1}^{\pi}\right) & =\rho_{t+1}^{\pi} .
\end{aligned}
$$

Higher $\sigma_{t}^{\pi}$ implies more uncertainty about the price level. When $\rho_{t}^{\pi}$ is positive, the relationship between inflation and real activity is upward sloping similarly to an upward-sloping Phillips curve. When $\rho_{t}^{\pi}$ is negative, the Phillips curve is unstable potentially due to supply shocks or to shifting inflation expectations.

We model time variation in $\sigma_{t}^{\pi}$ and $\rho_{t}^{\pi}$ in the simplest possible manner by assuming that they follow two-state Markov switching processes, independent of each other and of all other shocks in the economy. Inflation uncertainty $\sigma_{t}^{\pi}$ and inflation cyclicality $\rho_{t}^{\pi}$ each take a low or a high value:

$$
\sigma_{t}^{\pi} \in\left\{\sigma^{\pi, L}, \sigma^{\pi, H}\right\}, \rho_{t}^{\pi} \in\left\{\rho^{\pi, L}, \rho^{\pi, H}\right\}
$$

The probabilities of going from state $\sigma^{\pi, X}$ to $\sigma^{\pi, Y}$ and of going from state $\rho^{\pi, X}$ to $\rho^{\pi, Y}$ are:

$$
p\left(\sigma^{\pi, X} \rightarrow \sigma^{\pi, Y}\right), p\left(\rho^{\pi, X} \rightarrow \rho^{\pi, Y}\right)
$$

\section{E. Default Decision}

A firm's default decision depends on the initial level of debt, aggregate real shocks, aggregate nominal shocks and idiosyncratic real shocks.

\footnotetext{
${ }^{4}$ It is important for our quantitative results that expected inflation is persistent. The assumption of an exact random walk is primarily for analytical tractability.
} 
Corporate debt promises a fixed nominal payment after two periods, when the firm pays a liquidating dividend. We denote logs by small letters throughout. All firms in cohort $t$ are identical ex ante and choose initial $\log$ leverage $l_{t}$, where $b_{t}^{\$}$ is the log nominal face value of debt:

$$
l_{t}=b_{t}^{\$}-2 \pi_{t}-k_{t+1}^{y} .
$$

Inflation persistence implies that the inflation shock in period $t+1$ enters twice into the $\log$ real liabilities of an old firm:

$$
b_{t+2}^{\text {real,old }}=l_{t}+k_{t+1}^{y}-2 \varepsilon_{t+1}^{\pi}-\varepsilon_{t+2}^{\pi} .
$$

Firm $i$ in cohort $t$ experiences identical and independent idiosyncratic shocks to log capital at times $t+1$ and $t+2$. The aggregate level of capital is unaffected by idiosyncratic shocks. Only the sum of time $t+1$ and $t+2$ idiosyncratic shocks, $a_{t+2}^{i, i d}$, affects the real firm value at time $t+2$. The reason is that production has constant returns to scale and that firms cannot adjust their capital structure in the intermediate period. We assume:

$$
a_{t+2}^{i, i d} \sim N\left(-\frac{1}{2}\left(\sigma^{i d}\right)^{2},\left(\sigma^{i d}\right)^{2}\right)
$$

Using (6) the log real value of an old firm at the end of period $t+2$ equals:

$$
v_{t+2}^{i, o l d}=k_{t+1}^{y}+r_{t+1}^{K}+r_{t+2}^{K}+a_{t+2}^{i, i d} .
$$

Equity holders have the option to default on debt payments and to receive a zero liquidating dividend. They optimally decide to default if and only if the real value of the firm (16) is less than 
its real liabilities $(14) \cdot 5$ Conditional on aggregate shocks, firms with the most adverse idiosyncratic shocks default:

$$
a_{t+2}^{i, i d}<\underbrace{l_{t}-2 \varepsilon_{t+1}^{\pi}-\varepsilon_{t+2}^{\pi}-r_{t+1}^{K}-r_{t+2}^{K}}_{\text {Survival Threshold } a_{t+2}^{*}} .
$$

Equation 17 formalizes the intuition that low inflation shocks $\varepsilon_{t+1}^{\pi}$ and $\varepsilon_{t+2}^{\pi}$ increase the survival threshold $a_{t+2}^{*}$ and defaults. Low productivity shocks at times $t+1$ and $t+2$ lower real returns on capital and also increase defaults. The real interest rate does not enter into the default threshold directly. However, a drop in real interest rates either reflects a fall in expected real growth rates or a change in real risk premia, which do affect credit risk.

\section{F. Stochastic Discount Factor}

We model a representative consumer with expected power utility over consumption, risk aversion $\gamma$, and discount rate $\beta$ :

$$
U_{t}=\mathbb{E}_{t} \sum_{s=t}^{\infty} \exp (-\beta(s-t)) \frac{C_{s}^{1-\gamma}}{1-\gamma} .
$$

The two-period stochastic discount factors for pricing two-period real and nominal payoffs are:

$$
\begin{aligned}
& M_{t, t+2}=\exp (-2 \beta)\left(C_{t+2} / C_{t}\right)^{-\gamma} \\
& M_{t, t+2}^{\$}=M_{t, t+2} / \exp \left(2 \pi_{t}+2 \varepsilon_{t+1}^{\pi}+\varepsilon_{t+2}^{\pi}\right) .
\end{aligned}
$$

\section{G. Capital Structure Choice}

Firms choose leverage according to a standard trade-off view of capital structure. We follow Gourio (2011) in assuming that firms receive benefits $\chi>1$ for each dollar of debt issued. Equity holders

\footnotetext{
${ }^{5}$ The firm never finds it optimal to default in its intermediate period because no debt payments come due during the intermediate period.
} 
of cohort $t$ firms choose capital $K_{t+1}^{y}$ and nominal liabilities $B_{t}^{\$}$ subject to the budget constraint:

$$
K_{t+1}^{y}=\underbrace{S_{t}}_{\text {Value of Newly Issued Equity }}+\chi \underbrace{q_{t}}_{\text {Two-Period Nominal Bond Price }} B_{t}^{\$} .
$$

Higher $\chi$ increases the incentive to raise leverage. There is a debate whether tax benefits are sufficiently large to explain observed leverage ratios (Graham (2000), Almeida and Philippon (2007)). We interpret $\chi$ broadly to include more general benefits and costs of debt, such as constraining managers from empire-building and reducing informational asymmetries (Jensen and Meckling (1976), Myers (1977), Myers and Majluf (1984), Jensen (1986)).

Equity holders trade off benefits of debt with expected bankruptcy costs. We assume that debt investors only recover a constant fraction $\theta<1$ of firm value in bankruptcy, see also Leland (1994). A lower recovery rate $\theta$ reduces the incentive to lever up. There exists an interior optimal leverage ratio if bankruptcy costs are sufficiently large relative to debt benefits. We formally assume that $\theta \chi<1$ (Gourio (2011)).

By imposing the resource constraint (5) we follow Gourio (2011) in assuming that bankruptcy costs and debt benefits are redistributive and do not have a direct effect on output. This simplifying assumption should not substantially affect the model results, as long as time variation in default rates is small relative to aggregate output fluctuations.

Let the functions $H, h$, and $\Omega$ give the default probability, marginal default probability, and average defaulted firm value conditional on the survival threshold $a_{t+2}^{*}$ :

$$
\begin{aligned}
H\left(a_{t+2}^{*}\right) & =\mathbb{P}\left(a_{t+2}^{i, i d}<a_{t+2}^{*}\right), \\
h\left(a_{t+2}^{*}\right) & =H^{\prime}\left(a_{t+2}^{*}\right), \\
\Omega\left(a_{t+2}^{*}\right) & =\mathbb{E}\left(\exp \left(a_{t+2}^{i, i d}\right) \mathbb{I}\left(a_{t+2}^{i, i d}<a_{t+2}^{*}\right)\right),
\end{aligned}
$$


where $\mathbb{I}$ denotes the indicator function. The price of a nominal long-term corporate bond at time $t$ equals the expected discounted value of cash flows. The ex ante price of the bond decreases in the default probability $H\left(a_{t+2}^{*}\right)$ and increases in the recovery rate $\theta \frac{\Omega\left(a_{t+2}^{*}\right)}{\exp \left(a_{t+2}^{*}\right)}$ :

$$
q_{t}=\mathbb{E}_{t}\left[M_{t, t+2}^{\$}(1-\underbrace{H\left(a_{t+2}^{*}\right)}_{\text {Default Rate }}+\underbrace{\theta \frac{\Omega\left(a_{t+2}^{*}\right)}{\exp \left(a_{t+2}^{*}\right)}}_{\text {Recovery }}]\right]
$$

Equity holders equate the marginal benefit of raising another dollar of debt with the increase in bankruptcy costs according to the first-order condition:

$$
0=\underbrace{-\chi(1-\theta) \mathbb{E}_{t}\left(M_{t, t+2}^{\$} h\left(a_{t+2}^{*}\right)\right)}_{\text {Marginal Bankruptcy Cost }}+\underbrace{(\chi-1) \mathbb{E}_{t}\left(M_{t, t+2}^{\$}\left(1-H\left(a_{t+2}^{*}\right)\right)\right)}_{\text {Marginal Benefit of Debt }} .
$$

Firms choose the optimal level of capital, yielding the first-order condition:

$$
\begin{aligned}
1 & =\mathbb{E}_{t}\left[M_{t, t+2} R_{t+1}^{K} R_{t+2}^{K} F_{t+2}\right] \\
F_{t+2} & =1-\underbrace{(1-\theta \chi) \Omega\left(a_{t+2}^{*}\right)}_{\text {Bankruptcy Cost }}+\underbrace{(\chi-1) \exp \left(a_{t+2}^{*}\right)\left(1-H\left(a_{t+2}^{*}\right)\right)}_{\text {Benefit of Debt }} .
\end{aligned}
$$

The Euler equation (27) says that the expected discounted return on capital, adjusted for bankruptcy costs and benefits of debt by the factor $F_{t+2}$, equals 1 .

Inflation affects the first-order conditions (26) and 27) through its impact on the survival threshold $a_{t+2}^{*}$. When inflation is more volatile or more procyclical the default threshold becomes more volatile and marginal bankruptcy costs increase in (26). While equity holders do not incur any bankruptcy costs upon default, debt investors require compensation for bankruptcy costs ex 
ante, incentivizing firms to reduce leverage ratios.

\section{Calibrated Model}

\section{A. Parameter Values and Model Moments}

We present two model calibrations, which solve individually for time-varying inflation volatility and time-varying inflation cyclicality. Model 1 focuses on stochastic inflation volatility and holds the correlation between inflation shocks and TFP shocks constant at 0 . Model 2 holds the volatility of inflation constant but assumes that the inflation-TFP correlation varies.

We focus on moderate inflation volatility to highlight the relevance of inflation risk for credit spreads even in a stable inflation environment. In Model 1 the standard deviation of annual inflation expectation shocks switches between $0 \%$ and $2 \%$. The higher volatility of $2 \%$ corresponds approximately to the U.S. experience in the early 1980s and is fifty percent smaller than our estimate of U.K. inflation volatility during the late 1970s. To focus on the impact of inflation volatility we set the inflation-TFP correlation to zero. Volatility states are persistent, consistent with a five year autoregressive coefficient for U.S. inflation volatility of 0.5 . The volatility process spends about two-thirds of its time in the low state.

In Model 2 we assume that the inflation-TFP correlation follows a symmetric process, switching between -0.6 and 0.6 , within the range of our empirical estimates for the inflation-stock return correlation in developed countries ${ }^{6}$ We study the impact of inflation cyclicality with moderate inflation uncertainty of $1 \%$ p.a. The average duration for each state is 15 years, consistent with three different regimes over a forty year period.

Parameter values are summarized in Table I. We face a trade-off in choosing the length of

\footnotetext{
${ }^{6}$ See Table IV.
} 
the time period. Five year time periods imply that seasoned corporate bond durations are slightly shorter than their empirical counterparts and that firm leverage and investment are constant for ten year periods.7 We choose standard values for the capital share, depreciation and the discount rate (Cooley and Prescott (1995)). We choose a risk aversion of 10, the upper bound of plausible coefficients of risk aversion considered by Mehra and Prescott (1985). Inflation volatility and inflation cyclicality affect the expected payoff on corporate debt in addition to the risk premium on the debt. With lower risk aversion, the expected payoff effect would be similar, but the risk premium effect would be smaller. We constrain trend growth to be equal to average U.S. real GDP growth between 1970 and 2009. The recovery rate in bankruptcy equals $40 \%$, consistent with the empirical evidence in Altman (2006). ${ }^{8}$ The debt benefit parameter is a free parameter and we choose $\chi=1.4$ to generate empirically plausible default rates. Almeida and Philippon (2007) calculate that tax benefits account for approximately $16 \%$ of the debt value, so our high benefits incorporate significant agency benefits of debt.

Table II reports calibrated asset price moments together with empirical U.S. moments from 1970 to 2009.9 The high volatility of TFP shocks and idiosyncratic shocks generate plausible levels of aggregate and idiosyncratic equity market volatility. We do not attempt to explain the equity volatility puzzle (Shiller (1971), LeRoy and Porter (1981)), which can be resolved if consumption and dividend growth contain a time-varying long-run component (e.g. Bansal and Yaron (2004)) or if preferences induce persistent fluctuations in risk premia (e.g. Campbell and Cochrane (1999)).

Unexpectedly low inflation also increases the real present value of off balance sheet liabilities,

\footnotetext{
${ }^{7}$ Welch (2004) finds that the mechanistic effects of stock returns can explain about $40 \%$ of movements in leverage ratios over a five-year horizon. Baker and Wurgler (2002) find that corporations are likely to raise more equity when their market valuations are relatively higher and that these effects can explain leverage ten years out.

${ }^{8} \mathrm{~A}$ recovery rate in the range of $40 \%$ to $50 \%$ is also consistent with the evidence in Cremers, Driessen, and Maenhout (2008), Glover (2011) and Coval, Jurek, and Stafford (2009).

${ }^{9}$ We simulate 250 runs of length 100 . Both model and empirical equity returns are defined as 10 year log nominal equity returns in excess of the continuously compounded ten year nominal interest rate.
} 
such as defined benefit pension plans, health care obligations for retired workers and operating leverage. This channel is potentially important, as illustrated by the salience of pension obligations during the United Air bankruptcy negotiations in the 2000s (Maynard (2005)). Shivdasani and Stefanescu (2010) and Bartram (2012) argue that consolidating post-retirement benefits can increase leverage by about a third. We therefore interpret model leverage of $41 \%$ broadly to include off balance sheet liabilities. 10

We compare the seasoned model credit spread to the average Moody's Baa over Aaa spread, which is based on secondary market prices rather than prices at issuance. Recent papers have argued that structural models of credit risk can only explain a small portion of empirical credit spreads while matching historically low default rates (Huang and Huang (2002)). We obtain high credit spreads with plausible default rates due to volatile TFP shocks and to high risk aversion. Leverage ratios of model seasoned firms are heterogeneous across firms and credit spreads are convex in leverage ratios, so the cross-section of firms further raises average credit spreads (Bhamra, Kuehn, and Strebulaev (2010a), (Bhamra, Kuehn, and Strebulaev 2010b)).

Our model raises the natural question why firms do not issue inflation-indexed debt. While firms in low inflation volatility countries almost exclusively issue nominal debt, markets with more volatile inflation histories, such as Chile and Israel, have substantial issuance of inflation-indexed corporate bonds ${ }^{11}$ If bond issuance in our sample countries is nominal by historical convention, it is plausible to think that inflation-indexed bond yields contain a liquidity premium. Such a liquidity premium could capture investors' and issuers' increased accounting and training expenses from holding both nominal and indexed bonds at the same time. U.S. government inflation-indexed bond yields, first issued in 1997, initially contained a substantial liquidity premium of over 50-100 bps (Pflueger and Viceira (2012)).

\footnotetext{
${ }^{10}$ Jin, Merton, and Bodie (2006) argue that firms' equity risk reflects the risk of a firm's pension plan.

${ }^{11}$ For a survey of the Chilean corporate bond market see Braun and Briones (2008).
} 
Our model is consistent with a nominal-only corporate bond market for plausible liquidity premia. Consider the problem of an infinitely small firm, which can deviate from the nominal-only equilibrium by issuing inflation-indexed bonds. In our calibrated model, such a firm does not find it optimal to deviate as long as the liquidity premium in corporate inflation-indexed bond yields is at least 29 bps. In the Supplementary Appendix $\mathrm{C}$ we derive the condition, which determines whether the firm finds it optimal to deviate.

\section{B. Model Implications for Credit Spreads}

Table III shows that calibrated credit spreads are highly sensitive to both inflation volatility and the inflation-stock correlation even for moderate levels of inflation volatility. We focus on seasoned credit spreads, which take into account non-optimal and heterogeneous firm leverage ratios and correspond most closely to empirical secondary market prices of corporate debt. We also use equity returns of seasoned firms for all equity moments. We estimate the following model regressions:

$$
\begin{array}{ll}
\text { Model 1: } & \text { spread }_{t}^{\text {seas }}=\lambda_{1}^{0}+\lambda_{1}^{\sigma^{\pi}} \sigma_{t}^{\pi}+\lambda_{1}^{\sigma^{e q}} \sigma_{t}^{e q}+\lambda_{1}^{D P} D P_{t}^{\text {seas }}+\lambda_{1}^{e q} r_{t}^{e q}+\lambda_{1}^{\pi} \varepsilon_{t}^{\pi}+\eta_{1, t}, \\
\text { Model 2: } & \operatorname{spread}_{t}^{\text {seas }}=\lambda_{2}^{0}+\lambda_{2}^{\rho^{\pi}} \rho_{t}^{\pi}+\lambda_{2}^{\sigma^{e q}} \sigma_{t}^{e q}+\lambda_{2}^{D P} D P_{t}^{\text {seas }}+\lambda_{2}^{e q} r_{t}^{e q}+\lambda_{2}^{\pi} \varepsilon_{t}^{\pi}+\eta_{2, t} .
\end{array}
$$

The simulation size corresponding approximately to 40 years of independent bi-annual data from five countries. Since in our in our data observations may be correlated over time and across countries, we have to exercise caution in interpreting the model standard errors. 12

A one percentage point increase in the standard deviation of annual inflation shocks on leads to an economically significant increase in credit spreads of 27 bps. The credit spread increases by 20

\footnotetext{
${ }^{12}$ We report means and standard deviations of regression coefficients from 500 simulated time series of length 100. To ensure that regressors are never perfectly collinear we add small measurement errors to the inflation shock and inflation risk variables. The standard deviations of the model measurement errors are approximately $2 \%$ of the standard deviations of the underlying parameters.
} 
bps as the inflation-stock return correlation increases by 100 percentage points. Inflation volatility and the inflation-stock correlation increase the regression $R^{2}$ by four and two percentage points respectively relative to regressions of credit spreads against equity returns and inflation shocks.

Equity returns, inflation shocks, equity volatility, the dividend-price ratio enter with the expected signs in Table III. Intuitively, capital structure adjustments are slow and therefore high equity returns and high inflation shocks decrease seasoned firms' leverage and decrease credit risk.

Our right-hand side variables can jointly account for over $80 \%$ of the variation in seasoned credit spreads. This high $R^{2}$ is unsurprising because the simulation generates model credit spreads as a function of real shocks, nominal shocks, and shocks to the inflation risk regime. At the same time we would not expect this high $\mathrm{R}^{2}$ to carry over to our empirical results, especially if empirical nominal and real shocks are imperfectly measured.

Figure 4 shows that inflation volatility and the inflation-TFP correlation increase credit spreads especially strongly when stock returns and inflation surprises are low 13 Intuitively, inflation risk matters most when stock returns are low or when inflation is unexpectedly low.

The asymmetry in Figure 4 is large relative to the slope coefficients of credit spreads onto inflation volatility and onto the inflation-stock correlation in Table III. For instance, the difference between high inflation volatility credit spreads and low inflation volatility credit spreads is $133 \mathrm{bps}$ larger in the lowest stock return quintile than in the middle stock return quintile.

\footnotetext{
${ }^{13}$ Figure 4 plots average seasoned credit spreads for different inflation risk regimes against lagged stock returns and inflation surprises. We average credit spreads within stock return and inflation shock quintiles and within inflation risk regimes. We simulate 500 runs of length 100. We use stock return and inflation shock quintiles from Model 2 for both Models 1 and 2. Model 1 has a large fraction of zero inflation realizations, and Model 1 inflation shock quintiles would therefore all include zero. While this is an unrealistic feature of the model, we think of it as a reduced form way of capturing a continuum of inflation volatilities.
} 


\section{Empirical Inflation Risk and Corporate Bonds}

We now consider how inflation volatility and the inflation-stock correlation empirically affect credit spread indices in six developed economies: Australia, Canada, Germany, Japan, the U.K., and the U.S.

\section{A. Data Description}

We compute corporate bond spreads as the difference between each country's corporate bond index yield minus a duration-matched government bond yield. All yields are continuously compounded, so our corporate bond spreads can also be expressed as log proportional spreads. Corporate bond spreads are therefore not mechanically related to inflation expectations through the effect of inflation expectations on the nominal term structure.

We obtain corporate bond yield indices, government bond yield indices, GDP growth, stock returns and CPI inflation from Global Financial Data (GFD). ${ }^{14}$ We find that average corporate bond durations are closely matched by government bond yields with fixed maturities. The corresponding government bond maturity is 10 years for Australia, Japan, and the U.K., 6 years for Germany, and 15 years for Australia. The U.S. credit spread is computed as the Moody's Baa over Aaa credit spread to adjust for liquidity and tax effects.

\footnotetext{
${ }^{14}$ According to GFD, the original sources for government bond yields and T-bill rates are the Reserve Bank of Australia, Bank of Canada, Deutsche Bundesbank, Bank of Japan, Bank of England, and Federal Reserve Bank. The original inflation sources are the Australian Bureau of Statistics, Statistics Canada, German Statistisches Bundesamt, Japanese Statistics Bureau, UK Central Statistical Office, and US Bureau of Labor Statistics. Quarterly GDP in Millions of national currency, volume estimates, OECD reference year, annual levels, seasonally adjusted is from OECD Stat. Stock returns correspond to the following equity indices: Australia ASX Accumulation Index, Canada S\&P/TSX-300 Total Return Index, Germany CDAX Total Return Index, Japan Topix Total Return Index, United Kingdom FTSE All-Share Return Index, and United States S\&P 500 Total Return Index. We are extremely grateful to Yoichi Matsubayashi for providing us with Japanese corporate bond yield data. Durations are estimated from bond maturities assuming that bonds sell at par following Campbell, Lo, and MacKinlay (1997), p. 408. For a description of the Moody's credit spreads, see http://credittrends.moodys.com/chartroom.asp?r=3. Table B.1 in the Supplementary Appendix lists further details on the corporate bond data sources and durations.
} 
We obtain empirical proxies for each country's equity volatility, inflation volatility, and inflationstock correlation using rolling backward-looking three year windows of quarterly real stock returns and inflation innovations. Unexpected inflation is the residual from a regression of quarterly log inflation onto its own four lags, the lagged T-bill, and seasonal dummies. Quarterly real stock return shocks are obtained as the residual from regressing quarterly real stock returns onto their own first lag.

Our baseline inflation forecasting regression is similar to those employed by Campbell, Sunderam, and Viceira (2011) and by Campbell and Shiller (1996). We have considered a forecasting relation that includes lagged stock returns as in Campbell, Sunderam, and Viceira (2011), but we find that lagged stock returns enter insignificantly and we therefore omit them.

A number of different inflation forecasting relations have been proposed in the literature. However, Atkeson and Ohanian (2001) argue that inflation over the past year outperforms Phillips curve-based inflation forecasts, which also include a measure of real activity, in the U.S. after 1984. We verify in the Supplementary Appendix that our empirical results are robust to the Atkeson and Ohanian (2001) model and to a wide range of reasonable inflation forecasting models from Stock and Watson (2008). We use consumer prices to measure inflation risk, but our results are robust to using different inflation indices.

We control for lagged stock returns, real GDP growth, unemployment and lagged inflation surprises. We explicitly control for equal-weighted market leverage ratios of non-financial Compustat firms over a shorter time period 15

We control for the volatility of real quarterly stock returns and the volatility of real quarterly

\footnotetext{
${ }^{15}$ Data for the U.S. and Canada are from Compustat North America and CRSP. Data for all other countries are from Compustat Global. We divide annual book debt values from the previous year end by the sum of the same book debt and quarterly market equity. Following Baker and Wurgler (2002), we define book debt as the sum of total liabilities and preferred stock minus deferred taxes and convertible debt. When preferred stock is missing, we use the redemption value of preferred stock. Corporate bond yield indices, such as the Moody's long-term yield indices, weight observations equally and therefore we control for equal-weighted market leverage.
} 
GDP growth. We also control for idiosyncratic stock return volatility, when available. We follow Campbell, Lettau, Malkiel, and Xu (2001) in decomposing individual daily stock returns into a market component, an industry component, and a firm component. Idiosyncratic volatility is calculated as the volatility of the firm component over the past quarter, averaged over all individual stocks 16

In our model the dividend-price ratio helps capture the time-varying risk of equity returns, while in a model of time-varying risk aversion, such as in Campbell and Cochrane (1999), it serves as a proxy for aggregate risk aversion. We therefore control for the dividend-price ratio from Datastream 17

Campbell, Sunderam, and Viceira (2011) have argued that the co-movement between nominal government bond returns and stock returns reflects time-varying inflation risk. If nominal longterm bond yields reflect long-term inflation expectations, the negative of the bond-stock return correlation may give another, quickly updating, measure of inflation cyclicality that focuses on the long-run component of inflation and that may be less sensitive to measurement error. However, the volatility of nominal government bond returns and the bond-stock correlation may also reflect real interest rate risk and, therefore also serve as important controls. We construct high frequency measures of bond return volatility and the bond-stock correlation from daily or weekly government bond and stock returns over the past quarter, using the highest frequency available. 18

\footnotetext{
${ }^{16}$ We obtain U.S. stock returns from CRSP, Canadian stock returns from Datastream, and all other country stock returns from Compustat Global. Industries are defined according to GIC classification codes.

${ }^{17}$ For a given MSCI index, the dividend yield is computed as the market-value weighted average dividend yield of all of its constituents. The dividend yield for an individual stock is based on its most recent annualized dividend rate (i.e., dividends per share) divided by the current share price.

${ }^{18}$ Bond volatility and the bond-stock correlation report the annualized standard deviation of changes in long-term nominal government bond yields and the correlation between changes in nominal government bond yields and stock returns, respectively. These measures are also equal to the volatility of government bond returns scaled by the bond duration and the negative of the correlation between government bond returns and stock returns, where bond returns are approximated using changes in yields. Our choice of units ensures that the inflation risk component in the bond volatility and the bond-stock correlation are comparable to the inflation-derived measures of inflation risk.
} 
Figure B.1 in the Supplementary Appendix compares the bond-stock correlation for the U.S. and the U.K. the breakeven-stock return correlation. Inflation risk, as captured by the breakeven inflation-stock return correlation, moves very closely with the bond-stock return correlation, supporting our interpretation of the bond-stock correlation as an additional measure of inflation risk. At the same time breakeven inflation also contains an inflation risk premium and a liquidity premium (Pflueger and Viceira (2011)).

Liquidity and especially the central role of U.S. Treasuries in global capital markets might drive a wedge between corporate bond yields and government bond yields. We therefore follow authors such as Chen, Collin-Dufresne, and Goldstein (2009) and use the Moody's Baa over Aaa corporate bond spread as a measure of credit risk in long-term U.S corporate bonds, but our results are robust to using the Baa-Treasury spread instead. We also report U.S. results with additional liquidity controls. 19 Corporate bond spreads during the financial crisis plausibly also indicated heightened credit risk, as evidenced by the fact that in $20095.4 \%$ of all Moody's rated corporate bond issuers defaulted (Moody's (2011)).

\section{B. Summary Statistics}

Summary statistics in Table IV reveal that both the volatility and the cyclicality of inflation have varied substantially over time in each country.

Average annualized inflation volatility ranges from $101 \mathrm{bps}$ for Germany to $161 \mathrm{bps}$ for the U.K., consistent with the average inflation volatility in our calibrated model. Inflation volatility displays significant time variation within each country with standard deviations ranging from 43

\footnotetext{
${ }^{19}$ Longstaff, Mithal, and Neis (2005) present evidence from Corporate Default Swaps that default risk accounts for the majority of the corporate bond spread across all rating categories, while Bao, Pan, and Wang (2011) argue that the illiquidity premium in highly-rated U.S. bonds increased substantially during the recent financial crisis. For a decomposition of interest rate swap spreads into liquidity and credit factors see Duffie and Singleton (1997).
} 
bps to 88 bps. Inflation volatility in our sample reached a peak of 412 bps in the U.K. during the 1970s, which exceeds the largest inflation volatility in our calibrated model by a factor of two.

The inflation-stock correlation, our measure of the slope of the Phillips curve, is negative or zero on average in every country. Its time variation within each country is substantial, with within country standard deviations of around 0.30.

Credit spreads average around 100 bps and have within country standard deviations between 32 bps to 98 bps. Rare negative values are most likely due to measurement error. The correlations of international credit spreads with U.S. credit spreads range from -0.17 for Japan to 0.54 for the U.K., as shown in Table B.2 in the Supplementary Appendix. International credit spreads therefore reflect risk above and beyond the risk incorporated into U.S. credit spreads.

Figure 5 plots credit spreads and inflation volatility for each country in our sample, which exhibit clear co-movement. Figure 5 also suggests that when a country has higher inflation volatility, it also has higher credit spreads. U.S. inflation volatility and credit spreads were both high in the 1970s and 1980s, but both inflation volatility and credit spreads were even more elevated in the U.K. during the same period.

Figure 7 shows visually the relationship between international credit spreads and the inflationstock correlation. The U.S. inflation stock correlation was at an all-time high at the end of 2010, indicating very procylical inflation. At the same time, credit spreads peaked during the financial crisis but came down towards the end of our sample. On the other hand, the U.S. inflation-stock return correlation was mostly negative during the 1970s and 1980s, indicating that supply shocks and shifting inflation expectations moved inflation and real outcomes in opposite directions. 20

\footnotetext{
${ }^{20}$ Using bond-market derived measures Wright (2010) argues that the cyclicality of inflation has increased since 1990 in most developed countries.
} 


\section{Benchmark Results}

Our main empirical tests in Table V proceed as follows. We first report a pooled regression of credit spreads against business cycle controls ${ }^{21}$ We then add inflation risk proxies and equity volatility and the dividend-price ratio. We then add time fixed effects and investigate the robustness of our results to additional controls and sub-periods.

Our baseline estimation regresses the corporate bond spreads in country $i$ in quarter $t$, spread $_{i, t}$, onto country fixed effects $\lambda_{0, i}$, measures of inflation volatility $\sigma_{i, t}^{\pi}$, the inflation-stock correlation $\rho_{i, t}^{\pi}$, equity volatility $\sigma_{i, t}^{e q}$, the dividend yield $D P_{i, t}$ and a vector of control variables $X_{t}$ :

$$
\operatorname{spread}_{i, t}=\lambda_{i}^{0}+\lambda^{\sigma^{\pi}} \sigma_{i, t}^{\pi}+\lambda^{\sigma^{e q}} \sigma_{i, t}^{e q}+\lambda^{D P} D P_{i, t}+\lambda^{\rho^{\pi}} \rho_{i, t}^{\pi}+\Lambda \times X_{i, t}+\eta_{t} .
$$

The standard errors take into account potential cross-country correlation, heteroskedasticity, and serial autocorrelation. We use Driscoll and Kraay (1998)'s extension of Newey and West (1987) standard errors with 16 lags, as implemented by Hoechle (2007). The structure of corporate bond markets varies significantly across countries and therefore all our regressions therefore contain country fixed effects. 22

Table $\mathrm{V}$ shows that inflation volatility and the inflation-stock correlation are important in explaining the time- and cross-country variation in credit spreads. Inflation volatility and the inflation-stock correlation both enter with positive, large, and significant coefficients, which are close to the model coefficients in Table III.

\footnotetext{
${ }^{21}$ We use sum of inflation surprises over the past three years, stock returns over the past three years, three year GDP growth, the three year change in unemployment, quarterly inflation surprises, stock returns, and GDP growth .

${ }^{22}$ For an analysis of the Japanese corporate bonds market, see Hattori, Koyama, and Yonetani (2001), who argue that default risk of the individual issuer is the most important determinant of corporate bond spreads in Japan after 1997. Reserve Bank of Australia Bulletin (2001) provides an overview of the Australian corporate bond market. Galati and Tsatsaronis (2001) and De Bondt and Lichtenberger (2003) study the transition of the Euro corporate bond market during the introduction of the Euro.
} 
We note the following results in Table V. First, inflation volatility increases the residual $\mathrm{R}^{2}$ by ten percentage points relative to a regression of credit spreads onto business cycle controls. In comparison, equity volatility and the dividend-price ratio raise the residual $\mathrm{R}^{2}$ only by three percentage points. Including inflation volatility and the inflation-stock correlation in addition to equity volatility and the dividend-price ratio raises the residual $\mathrm{R}^{2}$ by nine percentage points. Taken together, the regressions in columns (1) through (5) show that inflation risk can explain at least as much variation in credit spreads as equity volatility and the dividend-price ratio.

Second, our benchmark estimation in column (5) shows that 58 bps move in inflation volatility, approximately one standard deviation in U.S. inflation volatility, is associated with a 14 bps increase in empirical credit spreads. A one standard deviation move in the inflation-stock correlation (38 percentage points for the U.S.) is associated with a $14 \mathrm{bps}$ increase in credits spreads. The magnitudes are economically meaningful relative to average credit spreads of around $100 \mathrm{bps}$. The empirical effect of inflation volatility on credit spreads in extremely close to the theoretical magnitude in Table III. The empirical slope coefficient of the inflation-stock correlation is somewhat larger than the theoretical magnitude in Table III, but within a similar order of magnitude.

The sensitivities of credit risk with respect to real growth shocks and inflation shocks play crucial roles in our proposed mechanism. We include inflation surprises to disentangle the effect of news about the level of inflation and inflation risk, which is especially important if inflation surprises and the second moments of inflation might be correlated. Quarterly and three-year inflation shocks enter negatively and in some specifications significantly, with magnitudes comparable to model slopes in Table III. Quarterly real GDP growth enters with a large and negative coefficient, but the coefficients on real growth variables need to be interpreted with caution because of collinearity between different real activity variables.

If our estimates of surprises to inflation expectations are accurate in terms of magnitude but 
their timing is measured with error, inflation surprises, but not inflation volatility might be measured with error. Measurement error of this nature might also bias estimates of the inflation-stock correlation towards zero, increasing our estimated empirical effect of the inflation-stock correlation on credit spreads.

The coefficients on inflation volatility and the inflation-stock correlation are remarkable stable across different specifications. Including time fixed effects in column (6) helps alleviate concerns that the results might be driven by any global omitted variable, such as global real interest rate risk, global growth risk or global time-varying liquidity. Excluding the financial crisis in column (7) shows that inflation volatility and the inflation-stock correlation enter similarly. From our theoretical analysis, we would expect that inflation risk should have especially large effects on credit spreads during crises, and it is therefore unsurprising that the slope coefficients decrease in magnitude.

It is important to control for time varying GDP volatility, given that real GDP growth appears to help explain credit spreads. GDP volatility captures real uncertainty, similarly to equity volatility, and we find that it does not enter significantly in addition to equity volatility in column (8).

The international credit spread indices contain both callable and non-callable bonds. We include the slope of the yield curve and the nominal T-bill to partly control for the embedded call option of callable bonds in column (8). Duffee (1998) shows that callability features can substantially affect credit spreads and that the value of the call option is related to these two variables. While nominal yields are likely to reflect inflation risk, and might therefore have a confounding effect, they plausibly also reflect investors' inflation expectations. Both the nominal T-bill and the slope of the nominal yield curve enter with large, and negative coefficients, which is consistent with inflation expectations having a negative effect on credit spreads.

We include idiosyncratic equity volatility, market leverage, the return volatility of nominal 
government bonds, and the bond-stock correlation, available over a shorter sample period starting in 1989.

The bond-stock correlation and the bond volatility enter positively and significantly with a large regression coefficient in addition to inflation volatility and the inflation-stock correlation. The bond-stock correlation and the bond volatility control for real interest rate risk. However, to the extent that these variables reflect inflation risk, we interpret the results in column (9) also as additional evidence that inflation risk is priced into credit spreads

We have demonstrated that inflation risk is an important determinant of credit spreads in an international panel of forty years of quarterly data. We now investigate the relation (30) for the U.S. time series, which is likely to be especially familiar to readers and which allows us to include additional controls.

Although the smaller sample size in Table VI decreases the statistical power relative to Table V, we see that U.S. credit spreads are clearly related to inflation risk. Inflation risk again explains a similar amount of variation in credit spreads as equity volatility and the dividend-price ratio. U.S. credit spreads increase in inflation volatility with a large and significant coefficient. The inflationstock correlation coefficient is positive but not significant for this smaller sample.

Given that our sample includes the financial crisis of 2008-2009, it may be important to control for time-varying liquidity. We follow Campbell and Taksler (2003) by including the three month Eurodollar-LIBOR spread as a liquidity control. ${ }^{23}$ We also include the off-the-run and on-the-run U.S. nominal Treasury yields, which reflects liquidity in the U.S. Treasury market (Krishnamurthy (2002)). We think of the off-the-run spread as capturing a liquidity component that is common across U.S. Treasury and corporate bond markets. Both the Eurodollar-LIBOR spread and the off-

\footnotetext{
${ }^{23}$ We obtain the three month BBA LIBOR Rate from Bloomberg as "US0003m Index". It is available starting 1971.Q1. We construct the off-the-run spread as the difference between the Gurkaynak, Sack, and Wright (2010) 10 year par yield, which reflects off-the-run U.S. Treasuries, and the Bloomberg generic on-the-run U.S. 10 year Treasury yield.
} 
the-run spread enter with a positive and significant coefficient, as we would expect, but they leave the inflation volatility coefficient unchanged.

We control for the percent of zero daily returns in corporate bonds as a proxy for the timevarying liquidity of corporate bonds over a significantly shorter time period starting in 1993.Q1. Inflation volatility continues to enter with a very similar coefficient but the inflation-stock correlation coefficient is negative and insignificant over this subsample. The percent of zero daily returns, computed as in Chen and Wei (2007) from a sample of Datastream bonds, does not enter significantly into the regression.

A firm that is entirely financed with straight callable debt can call its its debt at the nominal face value when expected inflation and nominal interest rates fall and it may therefore be less subject to the risk of debt deflation. Inflation risk should therefore be more relevant for noncallable corporate bonds. The last two columns of Table VI show that the inflation volatility and the inflation-stock correlation enter more strongly for callable bonds than for non-callable bonds, potentially explaining why the inflation-stock correlation does not enter significantly into our full sample U.S. regressions.

We next explore the asymmetric model implications: the impact of inflation risk on credit spreads should be especially strong when either real stock returns or inflation surprises are low. The impact of inflation risk should be weak when stock returns or inflation surprises are high. Figure 7 shows empirical analogues to the theoretical relations in Figure 4, using a non-parametric approach.

We construct the top left panel in Figure 7 by splitting observations in each country into quintiles of real stock returns and into equal-sized subsamples for high and low inflation volatility. We sort by three year real stock returns for consistency with the construction of the inflation risk variables. Normalizing credit spreads in the middle real stock return quintile to zero focuses on the 
comparison between credit spread slopes across inflation risk regimes. The panel averages credit spreads across all countries within each inflation risk regime and quintile. The other panels are constructed similarly.

The empirical relationships between credit spreads, stock returns and inflation shocks in Figure 7 bear striking resemblance to the theoretical relationships in Figure 4. The top left panel in Figure 7 shows that the gap between credit spreads in the high and low inflation volatility regimes widens to $30 \mathrm{bps}$ in the lowest stock return quintile, indicating a larger put option in defaultable bonds when inflation uncertainty is greater. This gap is smaller but a substantial fraction of the theoretical analogue in Figure 4 of 133 bps.

The top right panel of Figure 7 similarly suggests that the impact of inflation volatility on credit spreads is larger when inflation is surprisingly low, even if the largest difference in credit spreads obtains in the second-lowest quintile of inflation shocks rather than the lowest.

In our benchmark empirical results, a one standard deviation move in either inflation volatility or the inflation-stock correlation is associated with a credit spread increase of at least $13 \mathrm{bps}$. In comparison, the empirical magnitudes in Figure 7 are large. However, the magnitudes in Figure 7 are smaller than the theoretical magnitudes in Figure 4. Besides measurement error, one potential reason is that in Figure 7 we average the above median and below median inflation risk regimes, while in Figure 4 we look at the largest and smallest values of inflation risk.

Further robustness checks, including individual country regressions, different inflation indices and empirical proxies for inflation shocks, and HP filtered explanatory variables are reported in the Supplementary Appendix. Table B.VI in the Supplementary Appendix shows that our benchmark results in Table V are robust to computing the U.S. credit spread with respect to a duration-matched government bond yield. 


\section{Expected Defaults and Risk Premia}

Inflation risk may raise physical default probabilities or default risk premia or both. An increase in the inflation-stock correlation increases both expected defaults and the correlation of defaults with marginal utility. We would therefore expect that the inflation-stock correlation induces a default risk premium and predicts corporate bond excess returns. The inflation volatility should primarily increase expected defaults and it might carry a smaller default risk premium, so we would expect it to predict expected defaults, but not necessarily corporate bond excess returns.

Table VII shows that U.S. inflation volatility robustly predicts Moody's defaults in annual regressions. Over a five year horizon, we find that a on standard deviation move in U.S. inflation volatility (58 bps) predicts a $10 \mathrm{bps}$ increase in default rates over the next five years, while controlling for the equity volatility, the dividend-price ratio and the same business cycle controls as in our credit spread regressions. This large magnitude shows empirically that inflation volatility mostly increases credit spreads through its impact on expected default rates, as predicted.

The inflation-stock correlation can predict defaults over some horizons, but the forecasting relation is insignificant over the five year horizon. Even over horizons where the inflation-stock correlation can predict future defaults, the effect of the inflation-stock correlation on expected defaults is only half as large as that on credit spreads estimated in Table V.

Table VIII shows that a higher inflation-stock correlation is associated with a statistically and economically significant increase in the default risk premium. A 100 percentage point higher inflation-stock correlation predicts an increase in corporate bond returns in excess of government bond returns of 168 bps over the next quarter. The same increase in the inflation-stock correlation predicts an increase in corporate over government bond returns of 442 bps over the next five years. On the other hand, inflation volatility does not predict corporate bond excess returns over horizons ranging from one to twenty quarters, consistent with our hypothesis that the inflation volatility 
should not affect the default risk premium.

A rough calculation allows us to compare the magnitudes in Table VIII to those in Table V. The Ibbotson U.S. long-term corporate bond index reflects bonds with 10 or more years to maturity. If the average bond duration is approximately 10 years, a 442 bps increase in expected corporate over government bond returns corresponds to a 44.2 bps increase in the corporate bond over government bond spread. This magnitude is comparable to the size of the effect of the inflation-stock correlation on corporate bond spreads in Table V. This rough calculation therefore suggests that the inflation-stock correlation affects credit spreads almost exclusively through the default risk premium and not through expected defaults.

\section{Conclusion}

While during the 1970s and 1980s investors and policy makers were concerned about stagflation, the two most recent U.S. recessions have been accompanied by low inflation, similarly to the Great Depression in the 1930s. This paper argues both theoretically and empirically that uncertainty about the long-run price level and the relationship of inflation with the business cycle are major macroeconomic determinants of corporate bond spreads.

In a real business cycle model with time-varying inflation risk, inflation persistence generates large effects of inflation risk on credit spreads. Using data on international corporate bond spreads, we provide new evidence that corporate bond investors price the time-varying risk of debt deflation.

As of December 2010, the Baa minus Aaa U.S. credit spread was 104 bps, very close to its sample average. This is in contrast to equity valuations, which were high relative to their historical average, suggesting that investors were reluctant to hold bonds relative to stocks ${ }_{24}^{24}$ We can

\footnotetext{
${ }^{24}$ The S\&P500 index dividend-price ratio was a full standard deviation below its sample average.
} 
rationalize this discrepancy, if one believes that policymakers will be unable to counteract deflation should another recession arrive. Our measures of inflation cyclicality were close to all-time highs, and our benchmark estimates attribute about 39 of the credit spread to the inflation-stock correlation.

Our results suggest fruitful avenues for further research. This paper suggests that investors attach an economically meaningful price to financial distress associated with deflation, highlighting the importance to better understand the macroeconomic and monetary policy determinants. A decomposition of time-varying inflation risk into macroeconomic shocks, such as cost push shocks and shocks to aggregate demand, and time-varying monetary policy, could be of particular interest to central banks around the world. Our analysis also suggests that corporate bond spreads may be useful measures of investors' deflationary concerns and for central banks' credibility in counteracting deflation.

Our findings have implications for firms' optimal capital structure. While our model only allows for one dimension of capital structure choice, in reality firms might adjust to changing inflation risk along a rich number of dimensions. Firms could issue inflation-indexed corporate debt, floating-rate debt, callable debt, or shorten shortening their maturity structure in response to inflation risk. However, each of these adjustments are likely to come at a cost, such as rollover risk (He and Xiong (2010), Acharya, Gale, and Yorulmazer (2010)), short-term variability in real payments (Campbell and Cocco (2003)) or agency costs (Bodie and Taggart (1978)).

\section{References}

Acharya, Viral V., Douglas Gale, and Tanju Yorulmazer, 2010, Rollover Risk and Market Freezes, NBER Working Paper w15674.

Almeida, Heitor, and Thomas Philippon, 2007, The Risk-Adjusted Cost of Financial Distress, Journal of Finance 62, 2557-2586. 
Altman, Edward, 2006, Default Recovery rates and LGD in Credit Risk Modeling and Practice: An Updated Review of the Literature and Empirical Evidence, NYU, mimeo.

Atkeson, Andrew, and L. E. Ohanian, 2001, Are Phillips Curves Useful for Forecasting Inflation?, Federal Reserve Bank of Minneapolis Quarterly Review 25, 2-11.

Baele, Lieven, G. Bekaert, and Koen Inghelbrecht, 2009, The Determinants of Stock and Bond Return Comovements, NBER Working Paper w15260.

Baker, Malcolm, and Jeffrey Wurgler, 2002, Market Timing and Capital Structure, Journal of Finance 57, $1-32$.

Ball, Laurence, 1992, Why does High Inflation Raise Inflation Uncertainty?, Journal of Monetary Economics 29, 371-388.

Ball, Laurence, and Stephen G. Cecchetti, 1990, Inflation and Uncertainty at Long and Short Horizons, Brookings Papers on Economic Activity 1, 215-245.

Bansal, Ravi, and Amir Yaron, 2004, Risks for the Long Run: A Potential Resolution of Asset Pricing Puzzles, Journal of Finance 59, 1481-1509.

Bao, Jack, Jun Pan, and Jiang Wang, 2011, The Illiquidity of Corporate Bonds, Journal of Finance 66, 911-946.

Bartram, Soehnke M., 2012, Post-Retirement Benefit Plans, Leverage, and Real Investment, Warwick Business School, mimeo.

Bernanke, Ben, and Mark Gertler, 1989, Agency Costs, Net Worth, and Business Fluctuations, American Economic Review 79, 14-31.

Bernanke, Ben S., 2002, Deflation: Making Sure "It" Doesn't Happen Here, Remarks by Governor Ben S. Bernanke Before the National Economists Club, Washington, D.C., Novermber 21, 2002.

Bhamra, Harjoat S., Adlai J. Fisher, and Lars-Alexander Kuehn, 2011, Monetary Policy and Corporate Default, University of British Columbia, mimeo.

Bhamra, Harjoat S., Lars-Alexander Kuehn, and Ilya A. Strebulaev, 2010a, The Levered Equity Risk Premium and Credit Spreads: A Unified Framework, Review of Financial Studies 23, 645-703.

Bhamra, Harjoat S., Lars-Alexander Kuehn, and Ilya A. Strebulaev, 2010b, Long Run Risks, Credit Markets, and Financial Structure, American Economic Review: Papers and Proceedings 100, 547-551.

Black, Fischer, and Myron Scholes, 1973, The Pricing of Options and Corporate Liabilities, Journal of Political Economy 81, 637-654.

Bodie, Zvi, and Robert A. Taggart, 1978, Future Investment Opportunities and the Value of the Call Provision on a Bond, Journal of Finance 33, 1187-1200. 
Braun, Matias, and Ignacio Briones, 2008, The Development of the Chilean Bond Market, in Ugo Panizza Eichengreen, Barry J., and Eduardo Borensztein, eds.: The Development of the Latin American Bond Markets (MIT Press, ).

Campbell, John Y., and Joao F. Cocco, 2003, Household Risk Management and Optimal Mortgage Choice, Quarterly Journal of Economics 118, 1449-1494.

Campbell, John Y., and John H. Cochrane, 1999, By Force of Habit: A Consumption-Based Explanation of Aggregate Stock Market Behavior, Journal of Political Economy 107, 205-251.

Campbell, John Y., Martin Lettau, Burton G. Malkiel, and Yexiao Xu, 2001, Have Individual Stocks Become More Volatile? An Empirical Exploration of Idiosyncratic Risk, Journal of Finance 56, 1-43.

Campbell, John Y., Andrew W. Lo, and A. Craig MacKinlay, 1997, The Econometrics of Financial Markets. (Princeton University Press).

Campbell, John Y., and Robert J. Shiller, 1996, A Scorecard for Indexed Government Debt, in Ben S. Bernanke, and Julio Rotemberg, eds.: National Bureau of Economic Research Macroeconomics Annual 1996 (MIT Press, ).

Campbell, John Y., Adi Sunderam, and Luis M. Viceira, 2011, Inflation Bets or Deflation Hedges? The Changing Risks of Nominal Bonds, Harvard University, mimeo.

Campbell, John Y., and Glen B. Taksler, 2003, Equity Volatility and Corporate Bond Yields, Journal of Finance 58, 2321-2349.

Chen, Long, David A. Lesmond, and Jason Wei, 2007, Corporate Yield Spreads and Bond Liquidity, Journal of Finance 62, 119-149.

Chen, Long, Pierre Collin-Dufresne, and Robert S. Goldstein, 2009, On the Relationship Between the Credit Spread Puzzle and the Equity Premium Puzzle, Review of Financial Studies 22, 3367-3409.

Collin-Dufresne, Pierre, R. S. Goldstein, and J. S. Martin, 2001, The Determinants of Credit Spread Changes, Journal of Finance 56, 2177-2207.

Cooley, Thomas F., and Edward C. Prescott, 1995, Frontiers of Business Cycle Research. (Princeton University Press).

Coval, Joshua D., Jakub W. Jurek, and Erik Stafford, 2009, Economic Catastrophe Bonds, American Economic Review 99, 628-666.

Cremers, K. J. Martijn, Joost Driessen, and Pascal Maenhout, 2008, Explaining the Level of Credit Spreads: Option-Implied Jump Risk Premia in a Firm Value Model, Review of Financial Studies 21, 2209-2242.

David, Alexander, and Pietro Veronesi, 2009, What Ties Return Volatilities to Price Valuations and Fundamentals?, NBER Working Paper w15563. 
De Bondt, Gabe, and Jung-Duk Lichtenberger, 2003, The Euro Area Corporate Bond Market: Where Do We Stand Since the Introduction of the Euro?, European Business Organization Law Review 4, 517-539.

De Fiore, Fiorella, Pedro Teles, and Oreste Tristani, 2011, Monetary Policy and the Financing of Firms, American Economic Journal: Macroeconomics 3, 112-142.

Driscoll, John C., and Aart C. Kraay, 1998, Consistent Covariance Matrix Estimation With Spatially Dependent Panel Data, Review of Economics and Statistics 80, 549-560.

Duffie, Darrell, and Kenneth J. Singleton, 1997, An Econometric Model of the Term Structure of InterestRate Swap Yields, Journal of Finance 52, 1287-1321.

Engle, Robert F., 1982, Autoregressive Conditional Heteroskedasticity with Estimates of the Variance of United Kingdom Inflation, Econometrica 50, 987-1007.

Ferson, Wayne E., and Campbell R. Harvey, 1991, The Variation of Economic Risk Premiums, Journal of Political Economy 99, 385-415.

Fisher, Irving, 1933, The Debt-Deflation Theory of Great Depressions, Econometrica 1, 337-357.

Fuhrer, Jeffrey C., 1997, The (Un)Importance of Forward-Looking Behavior in Price Specifications, Journal of Money, Credit, and Banking 29, 338-350.

Galati, Gabriele, and Kostas Tsatsaronis, 2001, The Impact of the Euro on Europe's Financial Markets, BIS Working Paper No. 100.

Glover, Brent, 2011, The Expected Cost of Default, University of Pennsylvania, mimeo.

Goldstein, Robert, Nengjiu Ju, and Hayne Leland, 2001, An EBIT-Based Model of Dynamic Capital Structure, Journal of Business 74, 483-512.

Gomes, Joao F., and Lukas Schmid, 2010, Levered Returns, Journal of Finance 65, 467-494.

Gourio, Francois, 2011, Credit Risk and Disaster Risk, Boston University, mimeo.

Graham, John R., 2000, How Big Are the Tax Benefits of Debt?, Journal of Finance 60, 1901-1941.

Gurkaynak, Refet S., Brian Sack, and Jonathan H. Wright, 2010, The TIPS Yield Curve and Inflation Compensation, American Economic Journal: Macroeconomics 2, 70-92.

Hackbarth, Dirk, Jianjun Miao, and Erwan Morellec, 2006, Capital Structure, Credit Risk, and Macroeconomic Conditions, Journal of Financial Economics 82, 519-550.

Hattori, Masazumi, Koji Koyama, and Tatsuya Yonetani, 2001, Analysis of Credit Spread in Japan's Corporate Bond Market, (in The Changing Shape of Fixed Income Markets: A Collection of Studies by Central Bank Economists, ).

He, Zhiguo, and Wei Xiong, 2010, Rollover Risk and Credit Risk, NBER Working Paper w15653. 
Hoechle, Daniel, 2007, Robust Standard Errors for Panel Regressions with Cross-Sectional Dependence, Stata Journal 7, 1-31.

Huang, Jing-zhi, and Ming Huang, 2002, How Much of the Corporate-Treasury Yield Spread is Due to Credit Risk?, Stanford University, mimeo.

Jensen, Michael C., 1986, Agency Costs of Free Cash Flow, Corporate Finance, and Takeovers, American Economic Review 76, 323-329.

Jensen, Michael C., and William H. Meckling, 1976, Theory of the Firm: Managerial Behavior, Agency Costs and Ownership Structure, Journal of Financial Economics 3, 305-360.

Jin, Li, Robert C. Merton, and Zvi Bodie, 2006, Do a firm's equity returns reflect the risk of its pension plan?, Journal of Financial Economics 81, 1-26.

Kiyotaki, Nobuhiro, and John Moore, 1997, Credit Cycles, Journal of Political Economy 105, 211-248.

Koijen, Ralph S. J., Otto van Hemert, and Stijn van Nieuwerburgh, 2009, Mortgage Timing, Journal of Financial Economics 3, 292-324.

Krishnamurthy, Arvind, 2002, The Bond/Old-Bond Spread, Journal of Financial Economics 66, 463-506.

Leary, Mark T., and M. R. Roberts, 2005, Do Firms Rebalance Their Capital Structures?, Journal of Finance $60,2575-2619$.

Leland, Hayne E., 1994, Corporate Debt Value, Bond Covenants and Optimal Capital Structure, Journal of Finance 49, 1213-1252.

Leland, Hayne E., and K. B. Toft, 1996, Optimal Capital Structure, Endogenous Bankruptcy, and the Term Structure of Credit Spreads, Journal of Finance 51, 987-1019.

LeRoy, Stephen F., and Richard D. Porter, 1981, The Present Value Relation: Tests Based on Variance Bounds, Econometrica 49, 555-577.

Li, Lingfeng, 2002, Macroeconomic Factors and the Correlation of Stock and Bond Returns, Yale ICF Working Paper No. 02-46.

Longstaff, Francis A., Sanjay Mithal, and Eric Neis, 2005, Corporate Yield Spreads: Default Risk or Liquidity? New Evidence from the Credit Default Swap Market, Journal of Finance 60, 2213-2253.

Longstaff, Francis A., and Eduardo S. Schwartz, 1995, A Simple Approach to Valuing Risky Fixed and Floating Rate Debt, Journal of Finance 50, 789-819.

Maynard, Micheline, 2005, United Air Wins Right to Default on Its Employee Pension Plans, The New York Times.

Mehra, Rajnish, and Edward C. Prescott, 1985, The Equity Premium: A Puzzle, Journal of Monetary Economics 15, 145-161. 
Merton, Robert C., 1974, On the Pricing of Corporate Debt: The Risk Structure of Interest Rates, Journal of Finance 29, 449-470.

Moody's, 2011, Corporate Default and Recovery Rates, 1920-2010, Moody's Investor Service Global Credit Research.

Myers, Stewart C., 1977, Determinants of Corporate Borrowing, Journal of Financial Economics 5, 147175.

Myers, Stewart C., and Nicolas S. Majluf, 1984, Corporate Financing and Investment Decisions when Firms Have Information that Investors Do Not Have, Journal of Financial Economics 13, 187-221.

Newey, Whitney K., and Kenneth D. West, 1987, A Simple, Positive Semi-Definite, Heteroskedasticity and Autocorrelation Consistent Covariance Matrix, Econometrica 55, 703-708.

Pflueger, Carolin E., and Luis M. Viceira, 2011, An Empirical Decomposition of Risk and Liquidity in Nominal and Inflation-Indexed Government Bonds, NBER Working Paper w16892.

Pflueger, Carolin E., and Luis M. Viceira, 2012, Appendix to An Empirical Decomposition of Risk and Liquidity in Nominal and Inflation-Indexed Bonds, Harvard University, available at http://www.people.fas.harvard.edu/ pflueger/papers.html.

Reserve Bank of Australia Bulletin, 2001, Corporate Bond Yields in Australia, 2001.

Shiller, Robert J., 1971, Do Stock Prices Move Too Much to be Justified by Subsequent Changes in Dividends?, American Economic Review 71, 421-436.

Shivdasani, Anil, and Irina Stefanescu, 2010, How Do Pensions Affect Corporate Capital Structure Decisions?, Review of Financial Studies 23, 1287-1323.

Stock, James H., and Mark W. Watson, 2007, Why has US Inflation Become Harder to Forecast?, Journal of Money Credit and Banking 39, 3-33.

Stock, James H., and Mark W. Watson, 2008, Phillips Curve Inflation Forecasts, NBER Working Paper w14322.

Viceira, Luis M., 2010, Bond Risk, Bond Return Volatility, and the Term Structure of Interest Rates, International Journal of Forecasting forthcoming.

Welch, Ivo, 2004, Capital Structure and Stock Returns, Journal of Political Economy 112, 106-130.

Wright, Jonathan H., 2010, Term Premia and Inflation Uncertainty: Empirical Evidence from an International Panel Dataset, American Economic Review 101, 1514-1534. 
Figure 1: U.S. Credit Spreads and Inflation Uncertainty

Differences between 50th and 10th percentiles and between 90th and 50th percentiles of forecasted inflation distribution from Survey of Professional Forecasters. Probabilities reflect mean responses for the probability that the annual-average over annual-average percent change in GDP deflator falls in a particular range. We interpolate the cumulative density function linearly to approximate quantiles. Quantiles are averages over the past eight quarters. We treat data for the 10th percentile as missing when the average probability of the lowest inflation range is greater than or equal to $15 \%$. 90th, 50th, and 10th percentiles reflect four quarter GDP price index inflation. Quarterly Baa mimus Aaa corporate bond spread from Moody's.

\section{Panel A: Inflation Uncertainty}

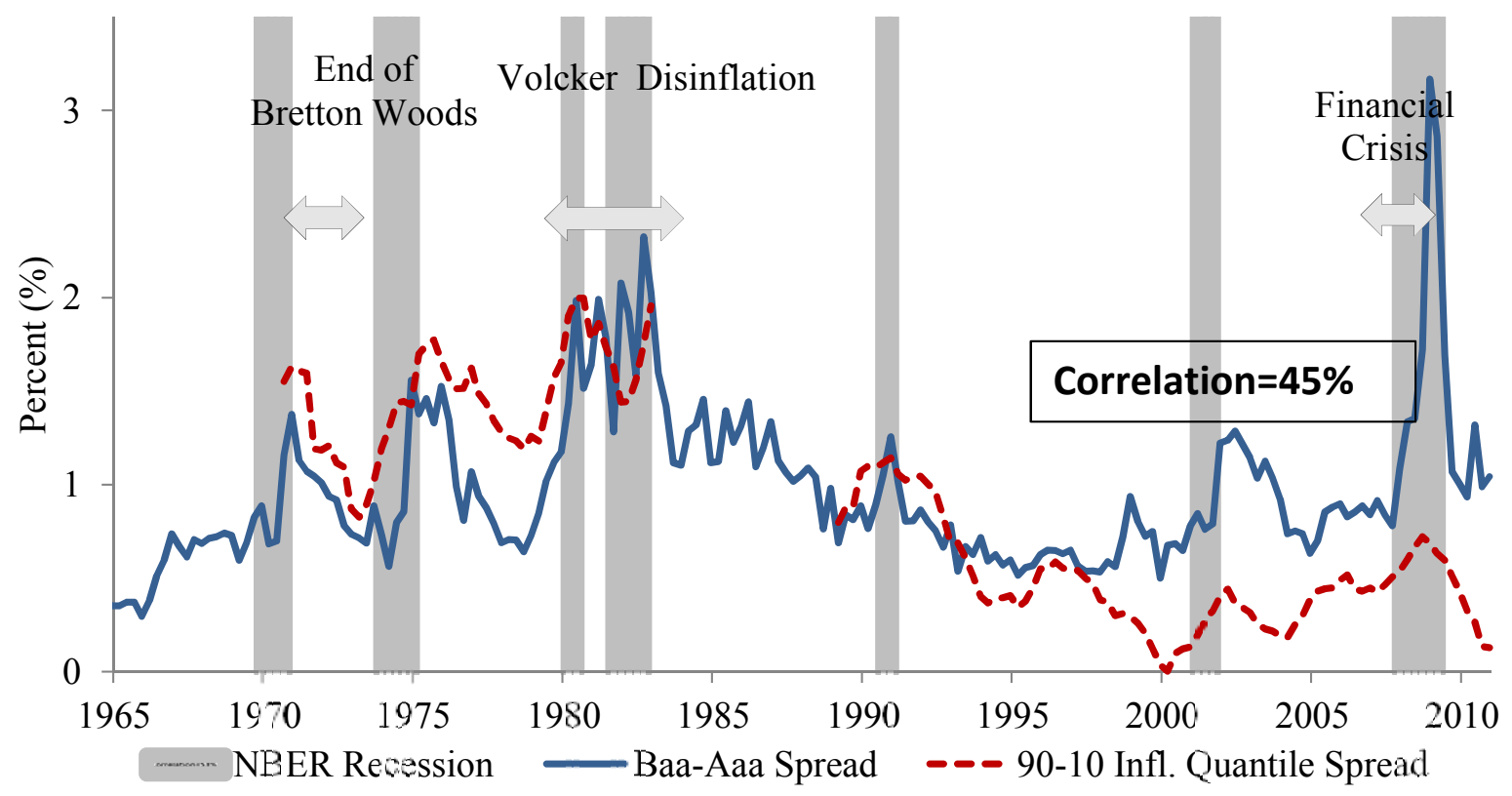

Panel B: Left Tail of Inflation Distribution

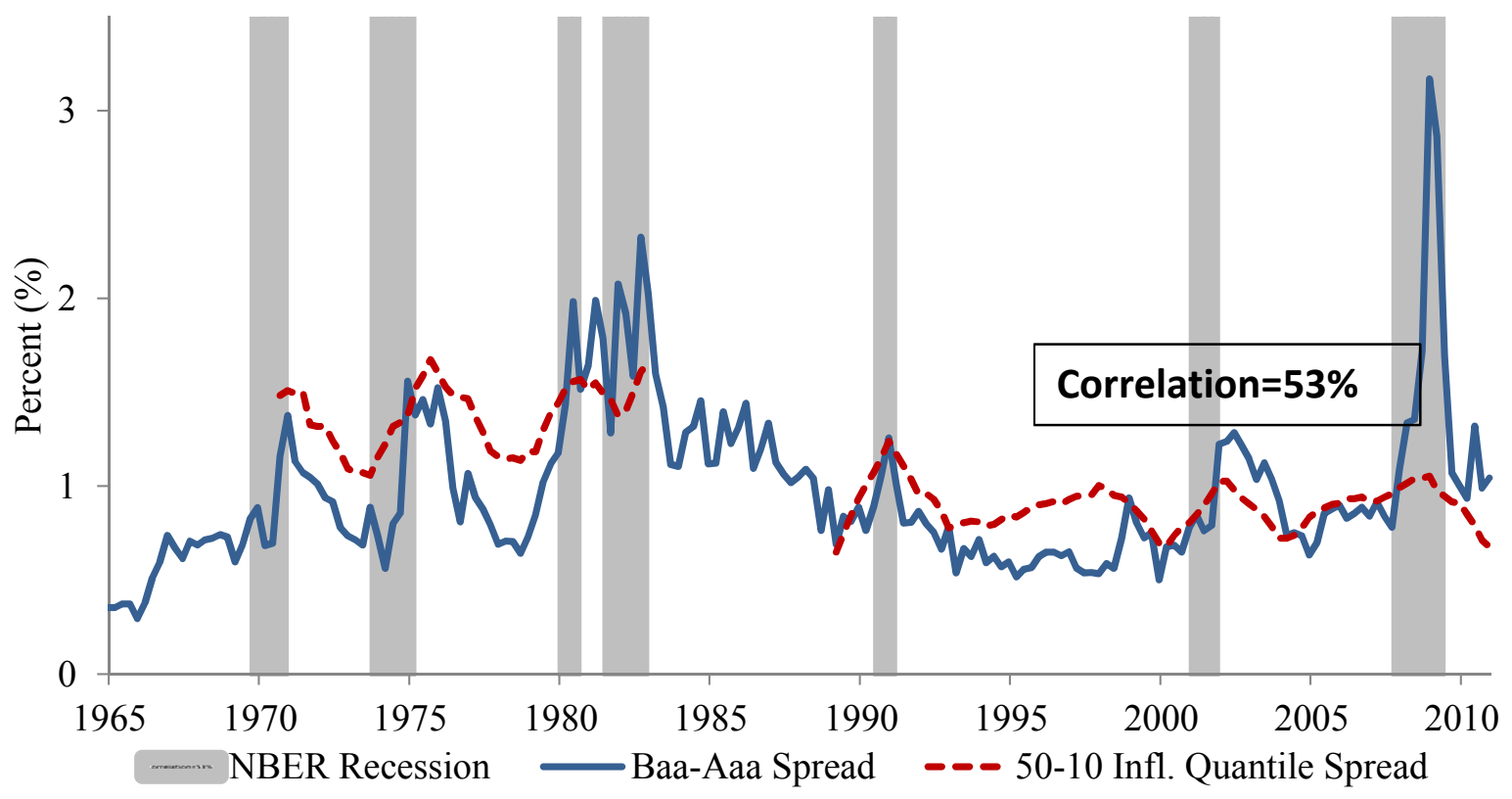




\section{Figure 2: Contingent Claim Payoff Profiles}

Expected real payoffs of nominal default-free and nominal corporate bonds conditional on the underlying real asset value and averaged over inflation realizations. Both the defaultable and default-free bonds are zero coupon with fixed and equal face values. The representative firm defaults when the real asset value is less than the real face value of the bond. In default, bond holders become residual claimants of the firm. The conditional expected real payoff of the default-free bond is $E[1 / \mathrm{P} \mid \mathrm{V}]$, where $\mathrm{P}$ is the price level and $\mathrm{V}$ is the asset value. Let $\mathrm{I}()$ denote the function that takes the value one if the condition in braces is true and zero otherwise. The conditional expected real payoff of the corporate bond is $\mathrm{E}[\mathrm{V} \mathrm{I}(\mathrm{VP}<1)+(1 / \mathrm{P}) \mathrm{I}(\mathrm{VP} \geq 1) \mid \mathrm{V}]$. We plot $0.2 \leq \mathrm{V} \leq 5$. We assume $\mathrm{P}=1, \mathrm{P}=\mathrm{V}^{0.2}, \mathrm{P}=\mathrm{V}^{-0.2}$ in Panels $\mathrm{A}, \mathrm{C}$, and $\mathrm{D}$, respectively. In Panel $\mathrm{B}, \log (\mathrm{P})$ is normally distributed with mean 0.18 and standard deviation 0.6 independently of $\mathrm{V}$. Panel $\mathrm{B}$ shows payoff profiles for fixed price levels $\mathrm{P}=1.5$ and $\mathrm{P}=0.75$ in dashed.
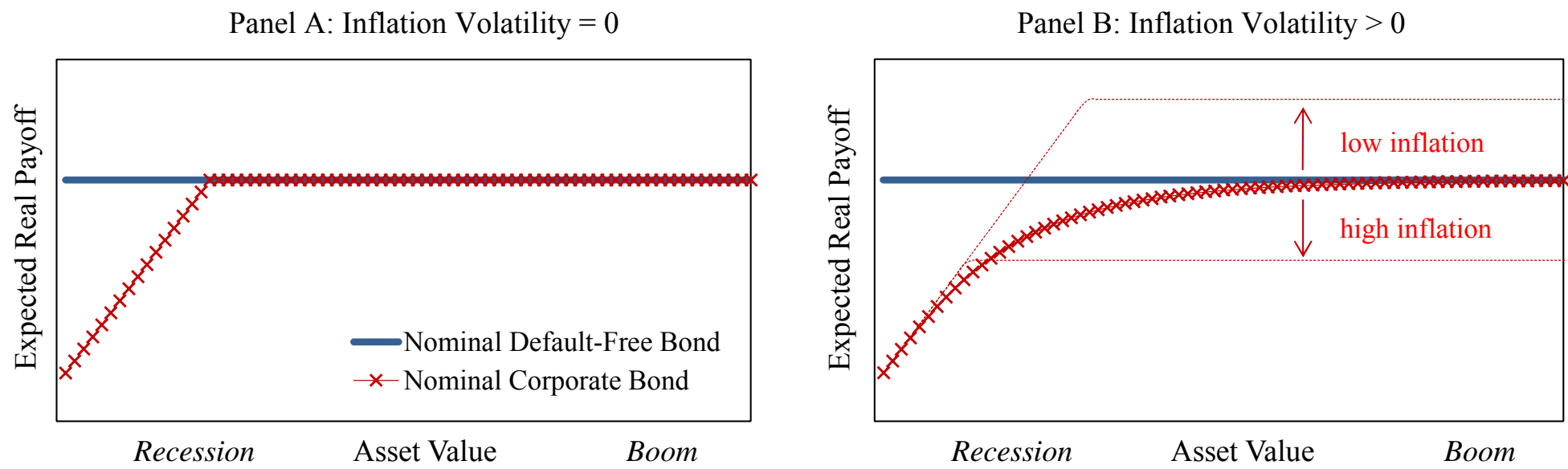

Panel C: Procyclical Inflation

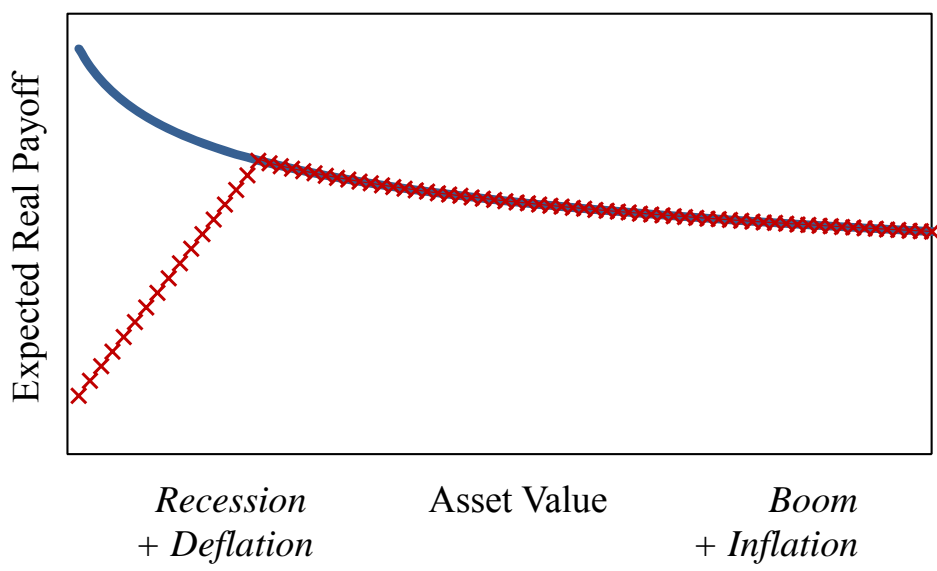

Panel D: Countercyclical Inflation

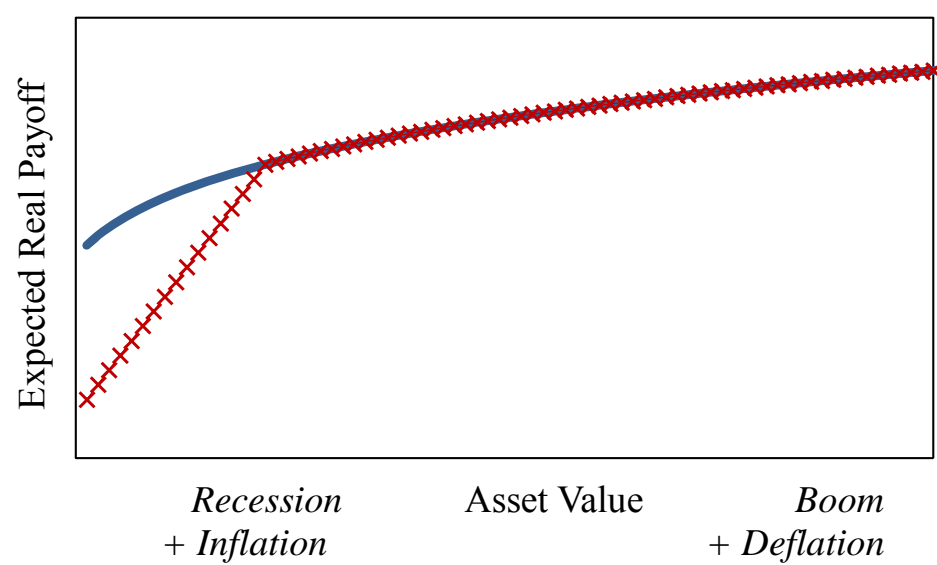


Figure 3: Timeline of Firm Cohort t

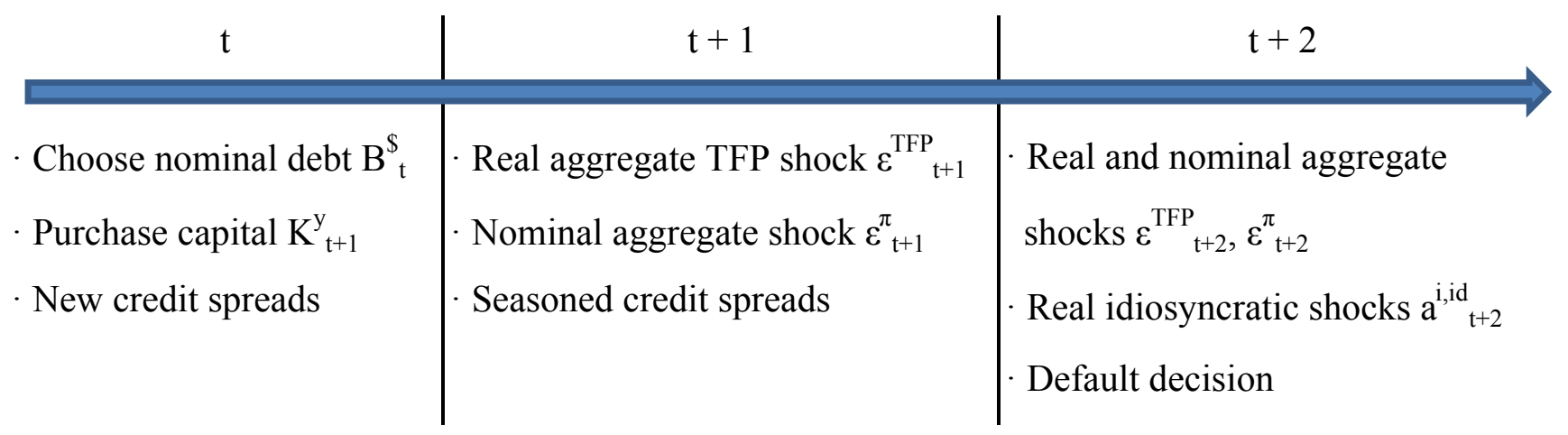


Figure 4: Asymmetric Model Predictions

Simulated average seasoned credit spreads versus stock returns and inflation shocks. Low and high inflation volatility correspond to $0 \%$ p.a. and $2 \%$ p.a. while inflation is uncorrelated with TFP shocks (Model 1). High and low inflation-TFP correlation correspond to 0.6 and -0.6 while inflation volatility is constant at $1 \%$ p.a. (Model 2). Credit spreads are normalized to zero in the middle quintile for both inflation risk regimes. For comparability, we use Model 1 stock return and inflation shock quintiles for both Models 1 and 2. A horizontal line is shown at 0 bps.
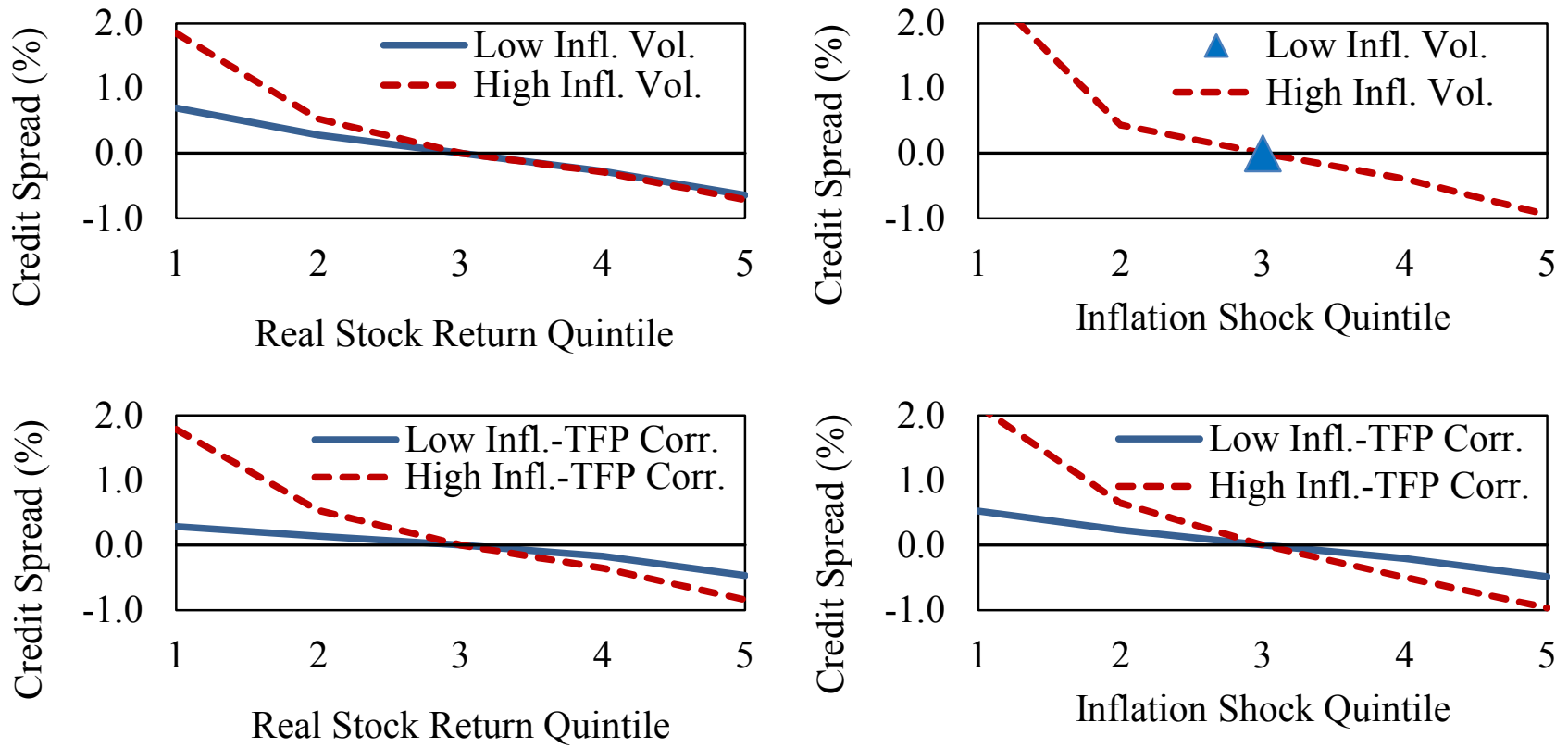


\section{Figure 5: International Credit Spreads and Inflation Volatility}

Quarterly credit spreads (bold) and inflation volatility (dashed) for Australia, Canada, Germany, Japan, the U.K., and the U.S. Credit spreads are investment grade corporate bond index yields in excess of duration-matched nominal government bond yields, except for the U.S. which is the Moody's BAA minus AAA spread. All yields are continuously compounded. Inflation volatility is computed using a 3 year backward-looking window of quarterly inflation surprises. Both variables are shown in percentage units.
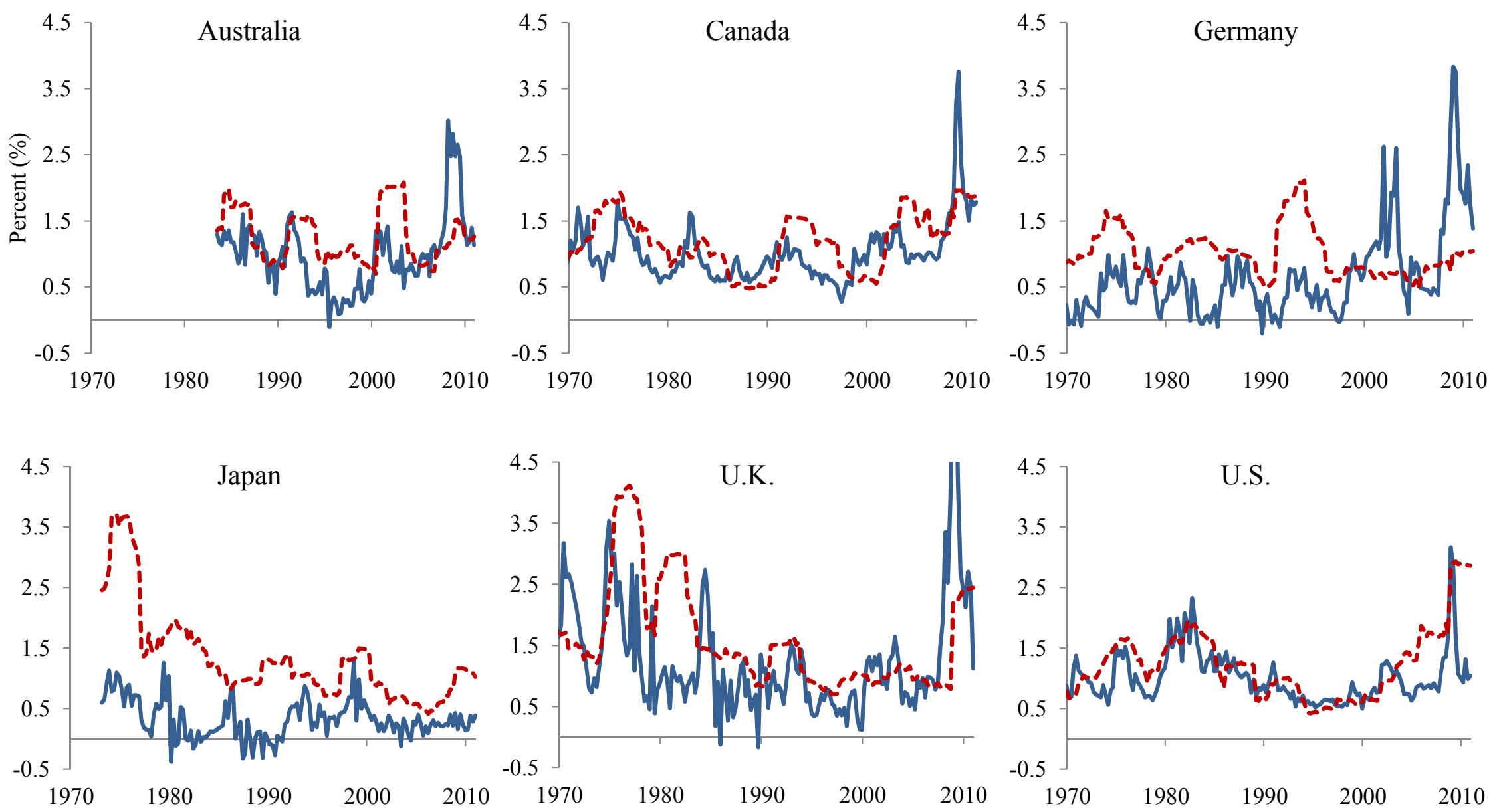

—Credit Spread (\%) - - - Inflation Volatility (\% Ann.) 


\section{Figure 6: International Credit Spreads and Inflation-Stock Correlation}

Quarterly credit spreads (bold) and inflation-stock correlation (dashed) for Australia, Canada, Germany, Japan, the U.K., and the U.S. Credit spreads are investment grade corporate bond index yields in excess of duration-matched nominal government bond yields, except for the U.S. which is the Moody's BAA minus AAA spread. All yields are continuously compounded. The inflation-stock correlation is computed using a 3-year backward-looking window of quarterly inflation surprises and stock returns as described in Table IV.
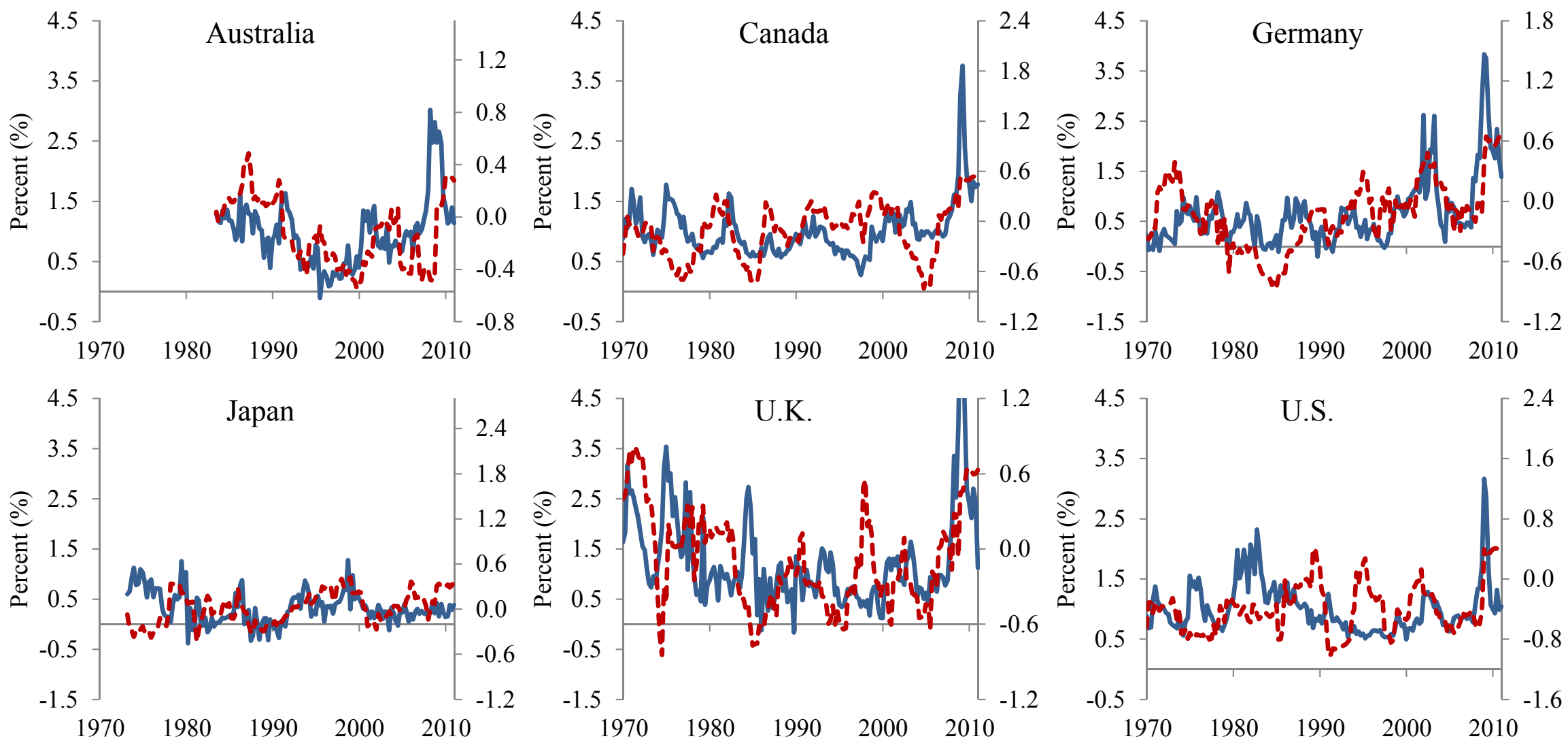

Credit Spread (\%) _ _ _- Inflation-Stock Correlation (Right Axis) 
Figure 7: Empirical Credit Spreads, Stock Returns and Inflation Shocks

Average international credit spreads within quintiles of lagged 3 year real stock returns, lagged 3 year inflation shocks, two inflation volatility regimes, and two inflation-stock correlation regimes. Inflation volatility and the inflation-stock correlation are estimated from quarterly inflation surprises and quarterly stock returns over the past three years. Low and high inflation risk regimes are defined relative to median values within each country. Credit spreads are normalized to zero in the middle quintile for both inflation risk regimes. A horizontal line is shown at 0 bps.
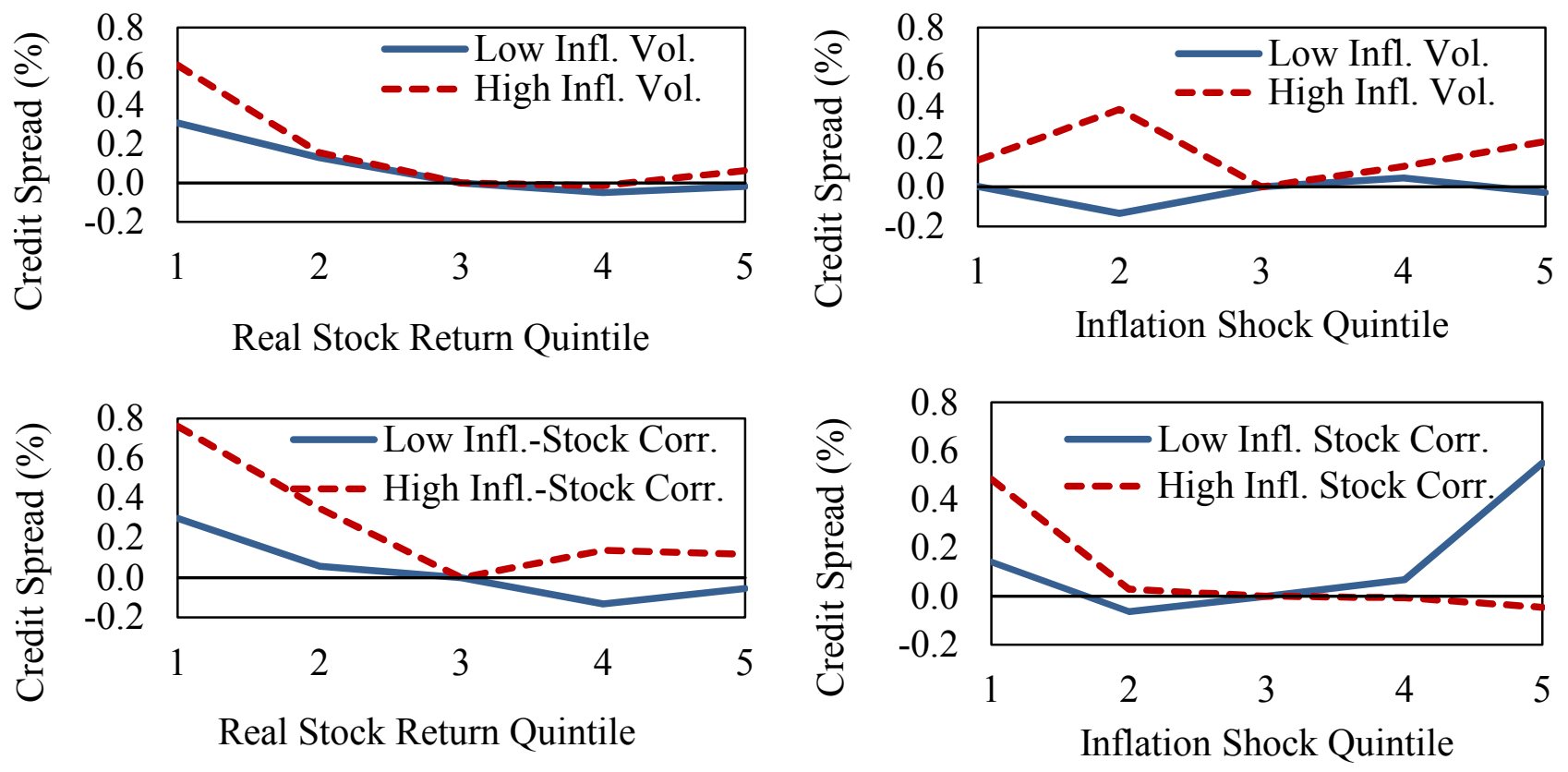


\section{Table I: Model Parameters}

* denotes parameters reported in per annum units. Annualized inflation volatility is the standard deviation of a one year inflation shock. Given that the state at time $t$ is $\mathrm{X}, \mathrm{p}(\mathrm{X} \rightarrow \mathrm{X})$ denotes the probability that the state at time $t+1$ is also $X$.

General Parameters

Period length

Discount rate

Risk aversion

Capital share

Depreciation

Trend growth

Volatility of TFP shock

Recovery rate

Tax benefit of debt

Idiosyncratic volatility

Model 1: Time-Varying Inflation Volatility

Inflation-TFP correlation

\begin{tabular}{cc}
$\rho^{\pi}$ & 0.00 \\
$\sigma^{\pi, \mathrm{H}}$ & $2 \% *$ \\
$\sigma^{\pi, \mathrm{L}}$ & $0 \% *$ \\
$\mathrm{p}\left(\sigma^{\pi, \mathrm{H}} \rightarrow \sigma^{\pi, \mathrm{H}}\right)$ & 0.60 \\
$\mathrm{p}\left(\sigma^{\pi, \mathrm{L}} \rightarrow \sigma^{\pi, \mathrm{L}}\right)$ & 0.80 \\
\hline
\end{tabular}

High inflation volatility

Low inflation volatility

Persistence of $\sigma^{\pi, \mathrm{H}}$

Persistence of $\sigma^{\pi, \mathrm{L}}$

$\mathrm{p}\left(\sigma^{\pi, \mathrm{L}} \rightarrow \sigma^{\pi, \mathrm{L}}\right)$

5 years

$3 \% *$

$\gamma$

$\alpha \quad 0.33$

$\delta \quad 8 \% *$

$\mu \quad 2.8 \% *$

$\sigma \quad 26 \% *$

$\theta \quad 0.40$

$\chi \quad 1.40$

$\sigma^{\text {id }} \quad 17 \% *$

Model 2: Time-Varying Inflation TFP Correlation

\begin{tabular}{lcr} 
Inflation volatility & $\sigma^{\pi}$ & $1 \% *$ \\
High inflation-TFP correlation & $\rho^{\pi, \mathrm{H}}$ & 0.60 \\
Low inflation-TFP correlation & $\rho^{\pi, \mathrm{L}}$ & -0.60 \\
Persistence of $\rho^{\pi, \mathrm{H}}$ & $\mathrm{p}\left(\rho^{\pi, \mathrm{H}} \rightarrow \rho^{\pi, \mathrm{H}}\right)$ & 0.70 \\
Persistence of $\rho^{\pi, \mathrm{L}}$ & $\mathrm{p}\left(\rho^{\pi, \mathrm{L}} \rightarrow \rho^{\pi, \mathrm{L}}\right)$ & 0.70 \\
\hline
\end{tabular}




\section{Table II: Empirical and Model Moments}

Empirical moments correspond to U.S. data from 1970 to 2009. Equity volatility is the standard deviation of 10 year log nominal equity returns minus the 10 year log nominal government yield. Firm volatility is the standard deviation of idiosyncratic 10 year log nominal stock returns of non-defaulted firms. The equity premium is the average 10 year log nominal equity return minus the 10 year $\log$ nominal government yield (adjusted for Jensen's Inequality). Seasoned credit spreads are computed as the Moody's BAA minus AAA corporate bond index yield. The historical default probability for 10 year investment grade bonds is from Almeida and Philippon (2007) for the U.S. between 1970 and 2001. Leverage is the aggregate book leverage ratio computed as long-term debt plus short-term debt divided by total assets from Compustat.

\begin{tabular}{lrrr} 
& $\begin{array}{r}\text { Empirical } \\
\text { U.S. 1970-2009 }\end{array}$ & $\begin{array}{r}\text { Model 1 } \\
\text { Time-Varying } \sigma^{\pi}\end{array}$ & $\begin{array}{r}\text { Model 2 } \\
\text { Time-Varying } \rho^{\pi}\end{array}$ \\
\hline Equity volatility (\% Ann.) & $18.4 \%$ & $18.5 \%$ & $18.0 \%$ \\
Firm volatility (\% Ann.) & $47.2 \%$ & $29.3 \%$ & $29.0 \%$ \\
Equity premium (\% Ann.) & $2.90 \%$ & $7.82 \%$ & $7.83 \%$ \\
$\mathrm{y}_{\mathrm{t}}{ }^{\text {gov, } 10}-\pi_{\mathrm{t}}$ & $2.50 \%$ & $2.80 \%$ & $2.72 \%$ \\
$\mathrm{y}_{\mathrm{t}}{ }^{\text {gov,10 }}-\mathrm{y}_{\mathrm{t}}{ }^{\text {gov,5 }}$ & $0.25 \%$ & $1.16 \%$ & $1.08 \%$ \\
New credit spread & & $1.18 \%$ & $1.23 \%$ \\
Seasoned credit spread & $1.01 \%$ & $1.64 \%$ & $1.53 \%$ \\
Default probability & $0.52 \%$ & $0.45 \%$ & $0.40 \%$ \\
Leverage & $25 \%$ & $41 \%$ & $40 \%$ \\
\hline
\end{tabular}




\section{Table III: Model Credit Spread Regressions}

We regress the model seasoned credit spread agains the variables listed below. Equity returns are one-period log seasoned equity returns. Inflation shocks are one-period changes in log inflation expectations. Equity return volatility is the standard deviation of $\log$ real returns on seasoned equity. The inflation-stock correlation is the correlation between log seasoned equity returns and shocks to log inflation expectations. The dividend-price ratio is the expected return on seasoned equity. In Panel A, inflation volatility switches between $0 \%$ p.a. and $2 \%$ p.a., and the inflation-TFP correlation is zero. In Panel B, inflation volatility is constant at $1 \%$ p.a., and the inflation-TFP correlation switches between -0.6 and 0.6 .

Panel A: Time-Varying Inflation Volatility (Model 1)

\begin{tabular}{|c|c|c|c|c|}
\hline Seas. credit spread (\%) & (1) & $(2)$ & (3) & (4) \\
\hline \multirow[t]{2}{*}{ Inflation volatility (Ann.) } & & 27.10 & & 27.13 \\
\hline & & $(9.37)$ & & $(8.51)$ \\
\hline \multirow[t]{2}{*}{ Equity volatility (Ann.) } & & & 8.69 & 2.2716 \\
\hline & & & $(6.67)$ & $(6.96)$ \\
\hline \multirow[t]{2}{*}{ Dividend-price ratio (Ann.) } & & & 17.51 & 30.16 \\
\hline & & & $(14.12)$ & $(14.63)$ \\
\hline \multirow[t]{2}{*}{ Equity return } & -1.36 & -1.36 & -1.71 & -1.45 \\
\hline & $(0.21)$ & $(0.21)$ & $(0.34)$ & $(0.34)$ \\
\hline \multirow[t]{2}{*}{ Inflation shock } & -10.75 & -10.76 & -10.58 & -10.70 \\
\hline & $(2.39)$ & $(2.16)$ & $(2.30)$ & $(2.11)$ \\
\hline \multirow[t]{2}{*}{ Constant } & 2.27 & 2.09 & 1.03 & 1.29 \\
\hline & $(0.12)$ & $(0.09)$ & $(0.50)$ & $(0.50)$ \\
\hline $\mathrm{R}^{2}$ & 0.75 & 0.79 & 0.81 & 0.85 \\
\hline \multicolumn{5}{|c|}{ Panel B: Time-Varying Inflation-TFP Correlation (Model 2) } \\
\hline Seas. credit spread $(\%)$ & $(1)$ & $(2)$ & $(3)$ & (4) \\
\hline \multirow[t]{2}{*}{ Inflation-stock correlation } & & 26.62 & & 19.70 \\
\hline & & $(9.75)$ & & $(11.94)$ \\
\hline \multirow[t]{2}{*}{ Equity volatility (Ann.) } & & & 10.84 & 4.91 \\
\hline & & & $(4.19)$ & $(6.12)$ \\
\hline \multirow[t]{2}{*}{ Dividend-price ratio (Ann.) } & & & 12.96 & 24.00 \\
\hline & & & $(10.53)$ & $(14.17)$ \\
\hline \multirow[t]{2}{*}{ Equity return } & -1.41 & -1.40 & -1.85 & -1.61 \\
\hline & $(0.21)$ & $(0.20)$ & $(0.26)$ & $(0.32)$ \\
\hline \multirow[t]{2}{*}{ Inflation shock } & -9.29 & -9.31 & -9.11 & -9.20 \\
\hline & (1.14) & (1.09) & $(0.97)$ & $(0.96)$ \\
\hline \multirow[t]{2}{*}{ Constant } & 2.18 & 2.15 & 0.83 & 1.21 \\
\hline & $(0.11)$ & $(0.11)$ & $(0.31)$ & $(0.42)$ \\
\hline $\mathrm{R}^{2}$ & 0.72 & 0.74 & 0.80 & 0.81 \\
\hline
\end{tabular}




\section{Table IV: Summary Statistics}

Credit spreads are computed as yields on investment grade corporate bond indices in excess of duration-matched nominal government bond yields, both continuously compounded. For the U.S. we show the Moody's BAA over AAA spread. Inflation volatility is the annualized standard deviation of three years of quarterly inflation innovations. The inflation-stock correlation is computed using three years of quarterly inflation and stock return innovations. Inflation innovations are residuals from regressing quarterly inflation onto its own four lags and seasonal dummies. Stock return innovations are residuals from regressing the quarterly real stock return onto its own first lag. Equity volatility is the annualized standard deviation of quarterly real stock return innovations. Dividend-price ratios are from MSCI. Idiosyncratic volatility is computed using one quarter of daily individual stock returns and GIC sector classifications and follows the methodology of Campbell et. al. (2001). Compustat equal-weighted market leverage is computed as total debt divided by total debt plus market value of equity. We approximate daily or weekly government bond log returns using changes in continuously compounded yields. Government bond volatility is the annualized standard deviation of daily or weekly nominal government bond returns over the past quarter divided by bond duration. The bond-stock correlation is the negative of the correlation between daily or weekly government bond returns and stock returns over the past quarter. All volatilities are standard deviations.

Panel A: Long Sample Period Variables

\begin{tabular}{llrrrrrr}
\hline & & Australia & Canada & Germany & Japan & U.K. & U.S. \\
Start date & & $1989 . Q 1$ & $1969 . Q 4$ & $1969 . Q 4$ & $1973 . Q 1$ & $1969 . Q 4$ & $1969 . Q 4$ \\
End date & & $2010 . Q 2$ & $2010 . Q 4$ & $2010 . Q 4$ & $2010 . Q 2$ & $2010 . Q 4$ & $2010 . Q 4$ \\
\hline Credit spread (\%) & mean & 0.94 & 1.02 & 0.65 & 0.33 & 1.28 & 1.02 \\
& std & 0.62 & 0.45 & 0.67 & 0.32 & 0.98 & 0.42 \\
& min & -0.10 & 0.28 & -0.20 & -0.38 & -0.16 & 0.50 \\
& max & 3.02 & 3.76 & 3.83 & 1.28 & 6.25 & 3.17 \\
\hline Inflation vol. (\%, Ann.) & mean & 1.21 & 1.19 & 1.01 & 1.33 & 1.61 & 1.23 \\
& std & 0.39 & 0.43 & 0.36 & 0.77 & 0.88 & 0.58 \\
& min & 0.70 & 0.45 & 0.48 & 0.42 & 0.70 & 0.42 \\
& max & 2.09 & 1.97 & 2.11 & 3.72 & 4.12 & 2.93 \\
\hline Inflation-stock correl. & mean & -0.18 & -0.03 & -0.15 & 0.00 & -0.12 & -0.26 \\
& std & 0.28 & 0.34 & 0.32 & 0.27 & 0.31 & 0.34 \\
& min & -0.61 & -0.77 & -0.83 & -0.56 & -0.70 & -0.90 \\
& max & 0.43 & 0.66 & 0.63 & 0.51 & 0.59 & 0.55 \\
\hline Equity Vol. (\%, Ann.) & mean & 14.93 & 16.19 & 19.50 & 19.61 & 18.57 & 16.06 \\
& std & 7.53 & 5.55 & 7.62 & 6.32 & 8.09 & 5.34 \\
& $\min$ & 6.72 & 7.87 & 7.80 & 5.51 & 5.85 & 5.66 \\
& $\max$ & 37.15 & 27.40 & 40.20 & 36.04 & 44.41 & 27.99 \\
\hline Div.-price ratio (\%, Ann.) & mean & 3.85 & 2.96 & 3.39 & 1.30 & 4.26 & 3.12 \\
& std & 0.87 & 1.00 & 1.12 & 0.66 & 1.24 & 1.32 \\
& $\min$ & 2.82 & 0.99 & 1.67 & 0.43 & 2.11 & 1.14 \\
& $\max$ & 6.95 & 5.67 & 6.20 & 2.86 & 10.46 & 6.14 \\
\hline
\end{tabular}


Panel B: Short Sample Period Variables

\begin{tabular}{llrrrrrr}
\hline & & Australia & Canada & Germany & Japan & U.K. & U.S. \\
Start date & & $1989 . Q 1$ & $1989 . Q 1$ & $1990 . Q 1$ & $1989 . Q 1$ & $1989 . Q 1$ & $1989 . Q 1$ \\
End date & & $2010 . Q 2$ & $2010 . Q 2$ & $2010 . Q 2$ & $2010 . Q 2$ & $2010 . Q 2$ & $2010 . Q 2$ \\
\hline Bond vol. (\%, Ann.) & mean & 0.80 & 0.66 & 0.54 & 0.49 & 0.66 & 0.72 \\
& std & 0.22 & 0.18 & 0.17 & 0.20 & 0.21 & 0.22 \\
& min & 0.42 & 0.28 & 0.28 & 0.19 & 0.30 & 0.40 \\
& max & 1.62 & 1.32 & 0.97 & 1.18 & 1.42 & 1.54 \\
\hline Bond-stock correl. & mean & -0.04 & 0.00 & -0.09 & 0.11 & -0.03 & -0.04 \\
& std & 0.35 & 0.32 & 0.39 & 0.31 & 0.41 & 0.42 \\
& min & -0.65 & -0.62 & -0.84 & -0.69 & -0.80 & -0.77 \\
& max & 0.78 & 0.68 & 0.72 & 0.64 & 0.72 & 0.77 \\
\hline Idiosync. vol. (\%, Ann.) & mean & 22.23 & 26.80 & 26.24 & 31.28 & 18.28 & 25.95 \\
& std & 12.03 & 5.20 & 9.02 & 7.46 & 12.36 & 7.61 \\
& $\min$ & 5.02 & 19.69 & 15.91 & 19.08 & 4.04 & 16.26 \\
& $\max$ & 57.68 & 54.67 & 54.95 & 58.00 & 52.75 & 50.39 \\
\hline Leverage (\%) & $\operatorname{mean}$ & 17.07 & 21.56 & 39.27 & 32.72 & 20.47 & 22.06 \\
& std & 7.16 & 7.62 & 15.87 & 9.71 & 5.91 & 6.17 \\
& $\min$ & 0.00 & 0.00 & 0.00 & 0.00 & 0.00 & 0.00 \\
& $\max$ & 40.76 & 35.53 & 63.12 & 47.40 & 31.67 & 33.67 \\
\hline
\end{tabular}


Table V: International Credit Spreads and Inflation Risk (1969.Q4-2010.Q4)

We report quarterly pooled regressions of credit spread indices against the variables listed below. We include credit spreads (\% Ann.) from the following countries: Canada, Germany, Japan, the U.K., and the U.S. We report Driscoll and Kraay (1998) standard errors accounting for crosscountry correlation and 16 lags. All regressions contain country fixed effects. The residual $\mathrm{R}^{2}$ reflects explanatory power in excess of fixed effects. Japan data starts in 1973.Q1. Variables are constructed as described in Table IV. * and ** denote significance at the 5\% and $1 \%$ levels, respectively.

\begin{tabular}{|c|c|c|c|c|c|c|c|c|c|}
\hline & $(1)$ & $(2)$ & (3) & (4) & $(5)$ & $(6)$ & $(7)$ & $(8)$ & $(9)$ \\
\hline \multicolumn{10}{|l|}{ Inflation risk } \\
\hline Inflation volatility (Ann.) & & $\begin{array}{r}30.92 * * \\
(8.82)\end{array}$ & $\begin{array}{r}29.40^{* *} \\
(7.44)\end{array}$ & & $\begin{array}{r}24.78^{* *} \\
(7.58)\end{array}$ & $\begin{array}{r}13.21^{*} \\
(5.26)\end{array}$ & $\begin{array}{r}14.23^{* *} \\
(4.81)\end{array}$ & $\begin{array}{r}26.20^{* *} \\
(6.88)\end{array}$ & $\begin{array}{r}27.67^{* *} \\
(5.05)\end{array}$ \\
\hline Inflation-stock correlation & & & $\begin{array}{r}42.02 * * \\
(12.81) \\
\end{array}$ & & $\begin{array}{r}47.75^{* *} \\
(12.66) \\
\end{array}$ & $\begin{array}{r}44.14 * * \\
(11.53) \\
\end{array}$ & $\begin{array}{r}30.17 * * \\
(10.77) \\
\end{array}$ & $\begin{array}{r}46.09^{* *} \\
(9.87) \\
\end{array}$ & $\begin{array}{r}38.04 * * \\
(8.31) \\
\end{array}$ \\
\hline \multicolumn{10}{|c|}{ Real uncertainty and other credit risk variables } \\
\hline Equity volatility (Ann.) & & & & $\begin{array}{r}1.37 \\
(0.83)\end{array}$ & $\begin{array}{r}1.12 \\
(0.86)\end{array}$ & $\begin{array}{l}1.64 * \\
(0.67)\end{array}$ & $\begin{array}{l}1.64 * \\
(0.66)\end{array}$ & $\begin{array}{r}1.81^{* *} \\
(0.67)\end{array}$ & $\begin{array}{r}0.35 \\
(0.79)\end{array}$ \\
\hline Dividend-price ratio (Ann.) & & & & $\begin{array}{l}8.24 * \\
(3.86)\end{array}$ & $\begin{array}{l}8.62^{*} \\
(4.01)\end{array}$ & $\begin{array}{r}17.01^{*} \\
(7.53)\end{array}$ & $\begin{array}{r}5.73 \\
(3.43)\end{array}$ & $\begin{array}{r}29.71^{* *} \\
(8.98)\end{array}$ & $\begin{array}{r}27.00^{* *} \\
(7.67)\end{array}$ \\
\hline GDP vol. & & & & & & & & $\begin{array}{r}-0.91 \\
(5.72)\end{array}$ & \\
\hline T-bill & & & & & & & & $\begin{array}{r}-12.09 * * \\
(3.61)\end{array}$ & \\
\hline Yield curve slope & & & & & & & & $\begin{array}{c}-8.91^{*} \\
(3.77)\end{array}$ & \\
\hline Idiosyncratic volatility (Ann.) & & & & & & & & & $\begin{array}{r}1.67^{* *} \\
(0.54)\end{array}$ \\
\hline Leverage & & & & & & & & & $\begin{array}{r}-1.08^{* *} \\
(0.33)\end{array}$ \\
\hline Bond volatility (Ann.) & & & & & & & & & $\begin{array}{r}39.81^{* *} \\
(12.14)\end{array}$ \\
\hline Bond-stock correlation & & & & & & & & & $\begin{array}{r}59.32 * * \\
(16.10) \\
\end{array}$ \\
\hline \multicolumn{10}{|c|}{ Business cycle and inflation shock variables } \\
\hline 3 Year inflation shock & $\begin{array}{r}1.94 \\
(2.02)\end{array}$ & $\begin{array}{r}-1.53 \\
(2.04)\end{array}$ & $\begin{array}{r}-1.42 \\
(1.82)\end{array}$ & $\begin{array}{r}0.66 \\
(1.85)\end{array}$ & $\begin{array}{r}-2.21 \\
(1.93)\end{array}$ & $\begin{array}{l}-2.81^{*} \\
(1.23)\end{array}$ & $\begin{array}{r}0.28 \\
(1.33)\end{array}$ & $\begin{array}{r}-1.49 \\
(1.77)\end{array}$ & $\begin{array}{r}-2.49 \\
(1.43)\end{array}$ \\
\hline 3 Year real stock return & $\begin{array}{r}-0.41^{* *} \\
(0.11)\end{array}$ & $\begin{array}{r}-0.41 * * \\
(0.10)\end{array}$ & $\begin{array}{r}-0.37^{* *} \\
(0.12)\end{array}$ & $\begin{array}{l}-0.25^{*} \\
(0.12)\end{array}$ & $\begin{array}{l}-0.22 \\
(0.12)\end{array}$ & $\begin{array}{r}0.10 \\
(0.15)\end{array}$ & $\begin{array}{r}-0.13 \\
(0.09)\end{array}$ & $\begin{array}{r}0.05 \\
(0.11)\end{array}$ & $\begin{array}{r}-0.04 \\
(0.09)\end{array}$ \\
\hline 3 Year GDP growth & $\begin{array}{r}-2.44 \\
(1.29)\end{array}$ & $\begin{array}{l}-2.33^{*} \\
(1.04)\end{array}$ & $\begin{array}{l}-1.04 \\
(0.67)\end{array}$ & $\begin{array}{l}-2.71^{*} \\
(1.34)\end{array}$ & $\begin{array}{l}-1.19 \\
(0.73)\end{array}$ & $\begin{array}{r}-0.28 \\
(1.89)\end{array}$ & $\begin{array}{r}-0.17 \\
(0.70)\end{array}$ & $\begin{array}{r}1.14 \\
(0.94)\end{array}$ & $\begin{array}{r}0.41 \\
(1.12)\end{array}$ \\
\hline 3 Year change unemployment & $\begin{array}{r}-2.35 \\
(3.36)\end{array}$ & $\begin{array}{r}-6.11 \\
(3.91)\end{array}$ & $\begin{array}{r}-3.33 \\
(3.27)\end{array}$ & $\begin{array}{r}-3.39 \\
(3.66)\end{array}$ & $\begin{array}{l}-3.56 \\
(3.60)\end{array}$ & $\begin{array}{l}-1.45 \\
(2.45)\end{array}$ & $\begin{array}{r}1.03 \\
(2.05)\end{array}$ & $\begin{array}{r}-0.52 \\
(2.31)\end{array}$ & $\begin{array}{r}1.94 \\
(2.34)\end{array}$ \\
\hline Quarterly inflation shock & $\begin{array}{r}-6.47 \\
(4.56)\end{array}$ & $\begin{array}{r}-4.85 \\
(4.13)\end{array}$ & $\begin{array}{r}-5.76 \\
(4.28)\end{array}$ & $\begin{array}{r}-5.89 \\
(4.31)\end{array}$ & $\begin{array}{r}-5.50 \\
(3.91)\end{array}$ & $\begin{array}{r}1.17 \\
(2.53)\end{array}$ & $\begin{array}{r}-0.52 \\
(1.79)\end{array}$ & $\begin{array}{l}-7.18^{*} \\
(3.33)\end{array}$ & $\begin{array}{r}-7.85^{* *} \\
(2.09)\end{array}$ \\
\hline Quarterly real stock return & $\begin{array}{l}-0.37 \\
(0.39)\end{array}$ & $\begin{array}{l}-0.40 \\
(0.39)\end{array}$ & $\begin{array}{r}-0.41 \\
(0.38)\end{array}$ & $\begin{array}{l}-0.37 \\
(0.39)\end{array}$ & $\begin{array}{l}-0.40 \\
(0.37)\end{array}$ & $\begin{array}{r}0.50 \\
(0.34)\end{array}$ & $\begin{array}{r}0.01 \\
(0.23)\end{array}$ & $\begin{array}{l}-0.49 \\
(0.30)\end{array}$ & $\begin{array}{l}-0.14 \\
(0.28)\end{array}$ \\
\hline Quarterly GDP growth & $\begin{array}{r}-11.09 \\
(5.76) \\
\end{array}$ & $\begin{array}{r}-11.13^{*} \\
(5.47) \\
\end{array}$ & $\begin{array}{r}-11.37^{*} \\
(5.20) \\
\end{array}$ & $\begin{array}{r}-10.90^{*} \\
(5.32) \\
\end{array}$ & $\begin{array}{r}-10.99^{*} \\
(4.68) \\
\end{array}$ & $\begin{array}{r}-2.88 \\
(3.07) \\
\end{array}$ & $\begin{array}{r}-5.04 * * \\
(1.87) \\
\end{array}$ & $\begin{array}{r}-10.21^{* *} \\
(3.27) \\
\end{array}$ & $\begin{array}{r}-11.30 * * \\
(3.09) \\
\end{array}$ \\
\hline Residual $\mathrm{R}^{2}$ & 0.20 & 0.26 & 0.30 & 0.23 & 0.32 & 0.32 & 0.28 & 0.43 & 0.59 \\
\hline $\begin{array}{l}\text { Time fixed effects } \\
\text { Period }\end{array}$ & Full & Full & Full & Full & Full & $\begin{array}{l}\text { Yes } \\
\text { Full }\end{array}$ & 69.Q4-07.Q4 & Full & 89.Q1-09.Q4 \\
\hline
\end{tabular}




\section{Table VI: U.S. Credit Spreads and Inflation Risk (1972.Q1-2010.Q4)}

We regress the quarterly U.S. Baa-Aaa Moody's credit spread against the variables listed below. The Treasury off-the-run spread reflects the difference between the Gurkaynak, Sack and Wright (2010) 10 year par yield and the Bloomberg generic on-the-run U.S. 10 year Treasury yield. The three month BBA LIBOR Rate is from Bloomberg (US0003m Index). Percent of zero daily corporate bond returns from Datastream following Chen, Lesmond, and Wei (2007). Callable corporate bond yields are an equal-weighted average of corporate bond issuances with some callability feature, while non-callable bonds are an equal-weighted average of bond issuances with no callability feature from Datastream. We obtain callable and non-callable corporate bond spreads by subtracting the 10 year U.S. Treasury yield, which closely matches the timevarying average duration of callable and non-callable corporate bond issuances. All other variables are as described in Table IV. We report Newey-West standard errors with 16 lags in parentheses. * and ** denote significance at the $5 \%$ and $1 \%$ levels, respectively.

\begin{tabular}{|c|c|c|c|c|c|c|c|c|c|c|}
\hline & (1) & (2) & (3) & (4) & (5) & (6) & (7) & (8) & (9) & (10) \\
\hline \multicolumn{11}{|l|}{ Inflation risk } \\
\hline \multirow[t]{2}{*}{ Inflation volatility (Ann.) } & & $39.99 * *$ & $39.90 * *$ & & $30.97 * *$ & $24.87 * *$ & $33.42 * *$ & $54.51 * *$ & $75.94 * *$ & $50.91 * *$ \\
\hline & & $(10.74)$ & $(10.40)$ & & $(7.84)$ & $(7.01)$ & $(4.93)$ & $(11.37)$ & $(17.24)$ & $(17.76)$ \\
\hline \multirow[t]{2}{*}{ Inflation-stock correlation } & & & 0.85 & & 7.91 & -1.99 & 2.46 & -15.78 & -0.91 & -18.93 \\
\hline & & & $(16.22)$ & & $(11.68)$ & $(10.92)$ & $(10.32)$ & $(9.63)$ & $(25.45)$ & $(21.80)$ \\
\hline \multicolumn{11}{|c|}{ Real uncertainty and other credit risk variables } \\
\hline \multirow[t]{2}{*}{ Equity volatility (Ann.) } & & & & 0.02 & 0.03 & 0.76 & 0.02 & -0.15 & 3.21 & 2.26 \\
\hline & & & & $(0.99)$ & $(0.55)$ & $(0.43)$ & $(0.29)$ & $(1.15)$ & $(2.39)$ & $(2.58)$ \\
\hline \multirow[t]{2}{*}{ Dividend-price ratio (Ann.) } & & & & $14.04 * *$ & $11.79 * *$ & 3.72 & $7.83 *$ & 23.56 & 11.27 & 5.79 \\
\hline & & & & $(2.77)$ & $(2.66)$ & $(4.60)$ & $(3.13)$ & $(19.25)$ & $(20.91)$ & $(21.08)$ \\
\hline \multirow[t]{2}{*}{ GDP vol. } & & & & & & 13.67 & & & & \\
\hline & & & & & & $(8.22)$ & & & & \\
\hline \multirow[t]{2}{*}{ T-bill } & & & & & & 2.20 & & & & \\
\hline & & & & & & $(2.80)$ & & & & \\
\hline \multirow[t]{2}{*}{ Yield curve slope } & & & & & & 2.48 & & & & \\
\hline & & & & & & $(3.76)$ & & & & \\
\hline \multirow[t]{2}{*}{ Idiosyncratic volatility (Ann.) } & & & & & & & $0.79 *$ & & & \\
\hline & & & & & & & $(0.38)$ & & & \\
\hline \multirow[t]{2}{*}{ Leverage } & & & & & & & 0.97 & & & \\
\hline & & & & & & & $(0.60)$ & & & \\
\hline \multirow[t]{2}{*}{ Bond volatility (Ann.) } & & & & & & & $50.02 * *$ & & & \\
\hline & & & & & & & $(7.74)$ & & & \\
\hline \multirow[t]{2}{*}{ Bond-stock correlation } & & & & & & & 9.50 & & & \\
\hline & & & & & & & $(5.89)$ & & & \\
\hline \multicolumn{11}{|l|}{ Liquidity variables } \\
\hline \multirow[t]{2}{*}{ Treasury off-the-run spread } & & & & & & $81.71 * *$ & & & & \\
\hline & & & & & & $(27.17)$ & & & & \\
\hline \multirow{2}{*}{\multicolumn{2}{|c|}{ Eurodollar over T-bill }} & & & & & $15.91 * *$ & & & & \\
\hline & & & & & & $(4.40)$ & & & & \\
\hline \multirow[t]{2}{*}{ Percent zero returns } & & & & & & & & -1.39 & & \\
\hline & & & & & & & & $(1.62)$ & & \\
\hline \multicolumn{11}{|c|}{ Business cycle and inflation shock variables } \\
\hline 3 Year inflation shock & -0.10 & -0.49 & -0.45 & -2.33 & -1.93 & -1.26 & $-2.49 *$ & $-17.62 * *$ & $-28.08 * *$ & $-28.60 * *$ \\
\hline & $(3.94)$ & $(2.93)$ & $(3.22)$ & $(2.60)$ & $(2.44)$ & $(2.29)$ & $(1.19)$ & (4.06) & (4.57) & (3.52) \\
\hline 3 Year real stock return & -0.26 & -0.14 & -0.13 & -0.23 & -0.10 & -0.26 & -0.14 & $-0.79 * *$ & $-1.23 * *$ & $-1.20 * *$ \\
\hline & $(0.26)$ & $(0.21)$ & $(0.24)$ & $(0.18)$ & $(0.21)$ & $(0.16)$ & $(0.11)$ & $(0.20)$ & $(0.32)$ & $(0.28)$ \\
\hline 3 Year GDP growth & -0.43 & 2.55 & 2.58 & -1.14 & 1.60 & -1.89 & 0.21 & 8.42 & 7.92 & 12.67 \\
\hline & $(2.44)$ & $(1.93)$ & $(2.00)$ & $(1.99)$ & $(1.90)$ & $(2.81)$ & $(1.65)$ & $(4.85)$ & $(11.33)$ & $(11.01)$ \\
\hline 3 Year change unemployment & 4.52 & 4.12 & 4.22 & 3.10 & 3.94 & -2.01 & 0.61 & -3.75 & -6.27 & 4.49 \\
\hline & $(4.75)$ & $(4.22)$ & $(5.37)$ & (3.72) & $(4.38)$ & $(5.30)$ & (4.53) & $(6.41)$ & $(18.22)$ & $(18.03)$ \\
\hline Quarterly inflation shock & $-16.75 * *$ & $-17.90 * *$ & $-17.91 * *$ & $-14.74 * *$ & $-16.11 * *$ & $-12.50 * *$ & $-10.84 * *$ & -0.46 & 8.63 & 3.49 \\
\hline & (4.19) & (4.63) & $(4.56)$ & (3.77) & (4.18) & (3.77) & (2.97) & $(2.58)$ & $(7.79)$ & $(5.20)$ \\
\hline Quarterly real stock return & -0.18 & -0.13 & -0.13 & -0.15 & -0.13 & 0.29 & 0.32 & -0.33 & -1.09 & $-1.35^{*}$ \\
\hline & $(0.48)$ & $(0.40)$ & $(0.39)$ & $(0.46)$ & $(0.39)$ & $(0.30)$ & $(0.36)$ & $(0.39)$ & $(0.61)$ & $(0.53)$ \\
\hline Quarterly GDP growth & -12.62 & $-12.21 *$ & $-12.21 *$ & $-12.47 *$ & $-12.18^{*}$ & $-10.99 * *$ & -3.91 & $-20.42 * *$ & $-50.70 *$ & $-56.38 * *$ \\
\hline & $(6.51)$ & $(5.88)$ & $(5.88)$ & $(6.19)$ & $(5.57)$ & $(3.31)$ & $(3.81)$ & $(7.40)$ & $(19.99)$ & $(18.51)$ \\
\hline Residual $\mathrm{R}^{2}$ & 0.39 & 0.54 & 0.54 & 0.55 & 0.65 & 0.75 & 0.82 & 0.86 & 0.89 & 0.86 \\
\hline & & & & & & 72.Q4- & 72.Q4- & 93.Q1- & 93.Q1- & 93.Q1- \\
\hline Period & Full & Full & Full & Full & Full & 09.Q1 & 09.Q1 & 10.Q4 & $10 . \mathrm{Q} 4$ & 10.Q4 \\
\hline Callability & All & All & All & All & All & All & All & All & Non-call. & Callable \\
\hline
\end{tabular}


Table VII: Annual Default Rates and U.S. Inflation Risk (1969-2010)

We regress annual global default rates of Baa rated firms from Moody's (2011) against the variables listed below. We report NeweyWest standard errors with 5 lags. Variables are constructed as described in Table IV. * and ** denote significance at the $5 \%$ and $1 \%$ levels, respectively.

\begin{tabular}{|c|c|c|c|c|c|c|c|c|c|c|c|}
\hline & (1) & (2) & (3) & (4) & $(5)$ & (6) & (7) & $(8)$ & (9) & $(10)$ & (11) \\
\hline Horizon (Years) & 1 & 2 & 3 & 4 & 5 & 5 & 5 & 5 & 5 & 5 & 5 \\
\hline \multicolumn{12}{|l|}{ Inflation risk } \\
\hline Inflation volatility (Ann.) & $\begin{array}{r}9.40 \\
(7.73)\end{array}$ & $\begin{array}{r}23.50^{*} \\
(11.46)\end{array}$ & $\begin{array}{r}26.88 * * \\
(6.35)\end{array}$ & $\begin{array}{r}20.74 * * \\
(4.87)\end{array}$ & $\begin{array}{r}17.30 * * \\
(4.38)\end{array}$ & & $\begin{array}{c}9.25 * * \\
(2.92)\end{array}$ & $\begin{array}{c}9.26^{*} \\
(3.73)\end{array}$ & & $\begin{array}{r}12.84 * * \\
(3.35)\end{array}$ & $\begin{array}{r}14.20^{*} \\
(5.58)\end{array}$ \\
\hline Inflation-stock correlation & $\begin{array}{r}11.27 \\
(12.10)\end{array}$ & $\begin{array}{c}22.84^{*} \\
(10.92)\end{array}$ & $\begin{array}{c}17.04^{*} \\
(8.23)\end{array}$ & $\begin{array}{c}13.77^{*} \\
(5.88)\end{array}$ & $\begin{array}{r}2.73 \\
(4.42)\end{array}$ & & & $\begin{array}{r}0.05 \\
(5.09)\end{array}$ & & $\begin{array}{r}0.34 \\
(5.56)\end{array}$ & $\begin{array}{r}-1.68 \\
(6.38)\end{array}$ \\
\hline \multicolumn{12}{|c|}{ Real uncertainty and other credit risk variables } \\
\hline Equity volatility (Ann.) & $\begin{array}{r}0.21 \\
(0.72)\end{array}$ & $\begin{array}{r}0.38 \\
(0.52)\end{array}$ & $\begin{array}{r}0.29 \\
(0.50)\end{array}$ & $\begin{array}{r}0.13 \\
(0.31)\end{array}$ & $\begin{array}{r}-0.25 \\
(0.18)\end{array}$ & & & & $\begin{array}{r}-0.03 \\
(0.30)\end{array}$ & $\begin{array}{r}0.12 \\
(0.24)\end{array}$ & $\begin{array}{r}0.15 \\
(0.32)\end{array}$ \\
\hline Dividend-price ratio (Ann.) & $\begin{array}{r}-1.70 \\
(1.87)\end{array}$ & $\begin{array}{r}-5.59 \\
(3.25)\end{array}$ & $\begin{array}{r}-5.25^{* *} \\
(1.85)\end{array}$ & $\begin{array}{c}-3.09^{*} \\
(1.19)\end{array}$ & $\begin{array}{l}-2.92 * \\
(1.15)\end{array}$ & & & & $\begin{array}{r}0.71 \\
(1.39)\end{array}$ & $\begin{array}{r}-9.25^{* *} \\
(2.82)\end{array}$ & $\begin{array}{r}0.35 \\
(5.93)\end{array}$ \\
\hline GDP vol. & & & & & & & & & & $\begin{array}{r}15.74 \\
(7.83)\end{array}$ & \\
\hline T-bill & & & & & & & & & & $\begin{array}{r}0.25 \\
(1.31)\end{array}$ & \\
\hline Yield curve slope & & & & & & & & & & $\begin{array}{r}2.85 \\
(1.57)\end{array}$ & \\
\hline Idiosyncratic volatility (Ann.) & & & & & & & & & & & $\begin{array}{r}0.26 \\
(0.52)\end{array}$ \\
\hline Leverage & & & & & & & & & & & $\begin{array}{r}-0.95 \\
(0.97)\end{array}$ \\
\hline Bond volatility (Ann.) & & & & & & & & & & & $\begin{array}{r}2.60 \\
(10.80)\end{array}$ \\
\hline Bond-stock correlation & & & & & & & & & & & $\begin{array}{r}-1.81 \\
(10.30)\end{array}$ \\
\hline \multicolumn{12}{|l|}{ Liquidity variables } \\
\hline Treasury off-the-run spread & & & & & & & & & & $\begin{array}{c}-15.63 \\
(12.09)\end{array}$ & \\
\hline Eurodollar over T-bill & & & & & & & & & & $\begin{array}{r}4.23 \\
(3.00)\end{array}$ & \\
\hline \multicolumn{12}{|c|}{ Business cycle and inflation shock variables } \\
\hline 3 Year inflation shock & $\begin{array}{r}-2.01 \\
(1.41)\end{array}$ & $\begin{array}{r}-1.14 \\
(1.08)\end{array}$ & $\begin{array}{r}-1.08 \\
(0.94)\end{array}$ & $\begin{array}{c}-0.22 \\
(0.68)\end{array}$ & $\begin{array}{r}-0.13 \\
(0.38)\end{array}$ & $\begin{array}{r}0.35 \\
(0.48)\end{array}$ & $\begin{array}{r}-0.10 \\
(0.35)\end{array}$ & $\begin{array}{r}-0.09 \\
(0.34)\end{array}$ & $\begin{array}{r}0.28 \\
(0.53)\end{array}$ & $\begin{array}{r}-0.20 \\
(0.67)\end{array}$ & $\begin{array}{r}0.21 \\
(0.67)\end{array}$ \\
\hline 3 Year real stock return & $\begin{array}{r}-0.07 \\
(0.15)\end{array}$ & $\begin{array}{r}0.22 \\
(0.11)\end{array}$ & $\begin{array}{r}0.20 \\
(0.12)\end{array}$ & $\begin{array}{c}0.22 * \\
(0.09)\end{array}$ & $\begin{array}{c}0.14^{*} \\
(0.06)\end{array}$ & $\begin{array}{r}0.09 \\
(0.07)\end{array}$ & $\begin{array}{r}0.12 \\
(0.07)\end{array}$ & $\begin{array}{r}0.12 \\
(0.06)\end{array}$ & $\begin{array}{r}0.09 \\
(0.08)\end{array}$ & $\begin{array}{r}0.15 \\
(0.09)\end{array}$ & $\begin{array}{r}0.10 \\
(0.08)\end{array}$ \\
\hline 3 Year GDP growth & $\begin{array}{r}3.94 \\
(2.27)\end{array}$ & $\begin{array}{r}1.78 \\
(2.73)\end{array}$ & $\begin{array}{r}1.60 \\
(2.22)\end{array}$ & $\begin{array}{r}2.46 \\
(1.71)\end{array}$ & $\begin{array}{r}1.01 \\
(0.92)\end{array}$ & $\begin{array}{r}1.21 \\
(1.25)\end{array}$ & $\begin{array}{r}1.15 \\
(0.94)\end{array}$ & $\begin{array}{r}1.15 \\
(0.96)\end{array}$ & $\begin{array}{r}1.31 \\
(1.19)\end{array}$ & $\begin{array}{r}-2.07 \\
(1.97)\end{array}$ & $\begin{array}{c}2.27^{* *} \\
(0.68)\end{array}$ \\
\hline 3 Year change unemployment & $\begin{array}{r}2.19 \\
(5.73)\end{array}$ & $\begin{array}{r}2.67 \\
(5.12)\end{array}$ & $\begin{array}{r}1.17 \\
(4.05)\end{array}$ & $\begin{array}{r}2.64 \\
(3.25)\end{array}$ & $\begin{array}{r}-0.44 \\
(1.28)\end{array}$ & $\begin{array}{r}0.27 \\
(1.94)\end{array}$ & $\begin{array}{r}-0.46 \\
(1.38)\end{array}$ & $\begin{array}{r}-0.46 \\
(1.39)\end{array}$ & $\begin{array}{r}0.39 \\
(1.83)\end{array}$ & $\begin{array}{r}-5.56 \\
(3.18)\end{array}$ & $\begin{array}{r}1.53 \\
(1.62)\end{array}$ \\
\hline Quarterly inflation shock & $\begin{array}{r}-7.36 \\
(6.80)\end{array}$ & $\begin{array}{r}7.06 \\
(11.72)\end{array}$ & $\begin{array}{r}3.80 \\
(6.67)\end{array}$ & $\begin{array}{r}-2.52 \\
(4.78)\end{array}$ & $\begin{array}{r}-1.23 \\
(4.14)\end{array}$ & $\begin{array}{c}-7.73^{*} \\
(3.32)\end{array}$ & $\begin{array}{r}-4.99 \\
(3.32)\end{array}$ & $\begin{array}{r}-4.99 \\
(3.31)\end{array}$ & $\begin{array}{c}-8.19^{*} \\
(3.61)\end{array}$ & $\begin{array}{r}0.48 \\
(4.89)\end{array}$ & $\begin{array}{r}0.21 \\
(4.25)\end{array}$ \\
\hline Quarterly real stock return & $\begin{array}{r}0.59 \\
(0.63)\end{array}$ & $\begin{array}{r}-0.04 \\
(0.34)\end{array}$ & $\begin{array}{r}0.19 \\
(0.21)\end{array}$ & $\begin{array}{c}0.46 * * \\
(0.16)\end{array}$ & $\begin{array}{c}0.55^{* *} \\
(0.11)\end{array}$ & $\begin{array}{c}0.54 * * \\
(0.10)\end{array}$ & $\begin{array}{c}0.61 * * \\
(0.10)\end{array}$ & $\begin{array}{c}0.61 * * \\
(0.10)\end{array}$ & $\begin{array}{c}0.57 * * \\
(0.10)\end{array}$ & $\begin{array}{c}0.55^{* *} \\
(0.16)\end{array}$ & $\begin{array}{r}0.50 * * \\
(0.11)\end{array}$ \\
\hline Quarterly GDP growth & $\begin{array}{r}-8.34 \\
(5.35) \\
\end{array}$ & $\begin{array}{r}-5.46 \\
(4.17) \\
\end{array}$ & $\begin{array}{r}-5.19 \\
(3.25) \\
\end{array}$ & $\begin{array}{r}-2.57 \\
(3.50) \\
\end{array}$ & $\begin{array}{r}-3.59 \\
(2.41) \\
\end{array}$ & $\begin{array}{r}-0.67 \\
(2.27) \\
\end{array}$ & $\begin{array}{r}-1.79 \\
(2.29) \\
\end{array}$ & $\begin{array}{r}-1.80 \\
(2.32) \\
\end{array}$ & $\begin{array}{r}-0.41 \\
(2.64) \\
\end{array}$ & $\begin{array}{r}-6.02 \\
(3.11) \\
\end{array}$ & $\begin{array}{r}-4.69^{*} \\
(2.25) \\
\end{array}$ \\
\hline $\mathrm{R}^{2}$ & 0.25 & 0.34 & 0.45 & 0.60 & 0.54 & 0.43 & 0.50 & 0.50 & 0.43 & $\begin{array}{r}0.69 \\
1972-\end{array}$ & 0.60 \\
\hline Period & Full & Full & Full & Full & Full & Full & Full & Full & Full & 2010 & Full \\
\hline
\end{tabular}


Table VIII: Predicting U.S. Corporate Bond Excess Returns (1969.Q4-2009.Q4)

Long-term corporate bond returns in excess of long-term government bond excess returns against lagged variables listed below. Corporate and government bond return indices from Ibbotson. For a lag horizon of $\mathrm{n}$ quarters we report Newey-West standard errors with $16+\mathrm{n}$ lags. $*$ and $* *$ denote significance at the $5 \%$ and $1 \%$ levels, respectively.

\begin{tabular}{|c|c|c|c|c|c|c|c|c|c|c|}
\hline & $(1)$ & $(2)$ & (3) & $(4)$ & $(5)$ & (6) & (7) & $(8)$ & (9) & $(10)$ \\
\hline Horizon (Quarters) & 1 & 4 & 12 & 20 & 1 & 1 & 1 & 1 & 1 & 1 \\
\hline \multicolumn{11}{|l|}{ Inflation risk } \\
\hline Inflation volatility (Ann.) & $\begin{array}{r}16.34 \\
(35.31)\end{array}$ & $\begin{array}{r}-74.41 \\
(95.12)\end{array}$ & $\begin{array}{r}-341.74 \\
(232.44)\end{array}$ & $\begin{array}{r}152.54 \\
(309.72)\end{array}$ & & $\begin{array}{r}27.77 \\
(34.68)\end{array}$ & $\begin{array}{r}33.40 \\
(29.73)\end{array}$ & & $\begin{array}{r}-78.96 \\
(86.14)\end{array}$ & $\begin{array}{r}44.59 \\
(47.47)\end{array}$ \\
\hline Inflation-stock correlation & $\begin{array}{r}168.09^{*} \\
(66.22)\end{array}$ & $\begin{array}{r}394.10 * * \\
(110.63)\end{array}$ & $\begin{array}{r}524.93 * * \\
(161.91)\end{array}$ & $\begin{array}{r}441.97 * * \\
(158.99)\end{array}$ & & & $\begin{array}{r}166.69 * * \\
(58.96) \\
\end{array}$ & & $\begin{array}{r}141.16^{*} \\
(54.26)\end{array}$ & $\begin{array}{r}114.42^{*} \\
(52.73)\end{array}$ \\
\hline \multicolumn{11}{|c|}{ Real uncertainty and other credit risk variables } \\
\hline Equity volatility (Ann.) & $\begin{array}{r}4.82 \\
(3.48)\end{array}$ & $\begin{array}{r}21.63 * \\
(8.81)\end{array}$ & $\begin{array}{r}33.09 * * \\
(9.43)\end{array}$ & $\begin{array}{r}8.17 \\
(8.61)\end{array}$ & & & & $\begin{array}{r}4.90 \\
(3.43)\end{array}$ & $\begin{array}{r}8.53 \\
(5.44)\end{array}$ & $\begin{array}{r}1.83 \\
(4.03)\end{array}$ \\
\hline Dividend-price ratio (Ann.) & $\begin{array}{r}17.23 \\
(14.86)\end{array}$ & $\begin{array}{l}61.03^{*} \\
(26.39)\end{array}$ & $\begin{array}{r}160.27 * * \\
(58.37)\end{array}$ & $\begin{array}{l}117.29 \\
(93.90)\end{array}$ & & & & $\begin{array}{r}17.52 \\
(13.59)\end{array}$ & $\begin{array}{r}61.29 * * \\
(22.39)\end{array}$ & $\begin{array}{r}-51.37 \\
(35.44)\end{array}$ \\
\hline GDP vol. & & & & & & & & & $\begin{array}{r}166.98 \\
(138.86)\end{array}$ & \\
\hline T-bill & & & & & & & & & $\begin{array}{r}-46.87^{* *} \\
(13.68)\end{array}$ & \\
\hline Yield curve slope & & & & & & & & & $\begin{array}{r}-61.16^{* *} \\
(18.20)\end{array}$ & \\
\hline Idiosyncratic vol. (Ann.) & & & & & & & & & & $\begin{array}{r}-0.14 \\
(3.05)\end{array}$ \\
\hline Leverage & & & & & & & & & & $\begin{array}{l}12.54 \\
(8.24)\end{array}$ \\
\hline Bond volatility (Ann.) & & & & & & & & & & $\begin{array}{l}155.48 \\
(91.66)\end{array}$ \\
\hline Bond-stock correlation & & & & & & & & & & $\begin{array}{r}-125.16 \\
(117.32)\end{array}$ \\
\hline \multicolumn{11}{|l|}{ Liquidity variables } \\
\hline Treasury off-the-run spread & & & & & & & & & $\begin{array}{r}-40.06 \\
(118.21)\end{array}$ & \\
\hline Eurodollar over T-bill & & & & & & & & & $\begin{array}{r}-1.06 \\
(20.70) \\
\end{array}$ & \\
\hline \multicolumn{11}{|c|}{ Business cycle and inflation shock variables } \\
\hline 3 Year inflation shock & $\begin{array}{r}-14.39 \\
(9.58)\end{array}$ & $\begin{array}{r}-13.86 \\
(11.79)\end{array}$ & $\begin{array}{r}9.00 \\
(20.87)\end{array}$ & $\begin{array}{r}41.36 \\
(24.84)\end{array}$ & $\begin{array}{l}-19.07 \\
(12.70)\end{array}$ & $\begin{array}{r}-19.40 \\
(12.36)\end{array}$ & $\begin{array}{l}-12.78 \\
(8.30)\end{array}$ & $\begin{array}{r}-20.97 \\
(13.95)\end{array}$ & $\begin{array}{r}-20.95 \\
(14.15)\end{array}$ & $\begin{array}{l}-24.11 * \\
(12.01)\end{array}$ \\
\hline 3 Year real stock return & $\begin{array}{r}-0.07 \\
(0.61)\end{array}$ & $\begin{array}{r}-0.41 \\
(1.60)\end{array}$ & $\begin{array}{r}0.47 \\
(2.10)\end{array}$ & $\begin{array}{r}6.62 \\
(3.94)\end{array}$ & $\begin{array}{l}-1.27 \\
(0.98)\end{array}$ & $\begin{array}{l}-1.20 \\
(0.92)\end{array}$ & $\begin{array}{r}-0.36 \\
(0.70)\end{array}$ & $\begin{array}{r}-0.94 \\
(0.90)\end{array}$ & $\begin{array}{r}0.97 \\
(0.51)\end{array}$ & $\begin{array}{r}-0.73 \\
(0.87)\end{array}$ \\
\hline 3 Year GDP growth & $\begin{array}{r}3.98 \\
(6.83)\end{array}$ & $\begin{array}{r}13.32 \\
(26.77)\end{array}$ & $\begin{array}{c}84.66^{*} \\
(36.10)\end{array}$ & $\begin{array}{r}167.83 * * \\
(49.48)\end{array}$ & $\begin{array}{r}3.01 \\
(7.82)\end{array}$ & $\begin{array}{r}5.17 \\
(7.90)\end{array}$ & $\begin{array}{r}9.62 \\
(6.90)\end{array}$ & $\begin{array}{r}-1.41 \\
(7.51)\end{array}$ & $\begin{array}{l}-38.93 \\
(34.42)\end{array}$ & $\begin{array}{r}-5.76 \\
(12.10)\end{array}$ \\
\hline 3 Year change unemploymes & $\begin{array}{l}35.20^{*} \\
(13.77)\end{array}$ & $\begin{array}{r}72.50 \\
(54.16)\end{array}$ & $\begin{array}{r}211.76^{* *} \\
(78.07)\end{array}$ & $\begin{array}{r}319.60^{* *} \\
(113.15)\end{array}$ & $\begin{array}{r}26.96 \\
(15.75)\end{array}$ & $\begin{array}{r}27.95 \\
(17.41)\end{array}$ & $\begin{array}{r}48.19^{* *} \\
(17.03)\end{array}$ & $\begin{array}{r}14.21 \\
(11.57)\end{array}$ & $\begin{array}{l}-13.93 \\
(45.12)\end{array}$ & $\begin{array}{r}10.04 \\
(18.13)\end{array}$ \\
\hline Quarterly inflation shock & $\begin{array}{r}34.33 \\
(62.06)\end{array}$ & $\begin{array}{r}-151.56^{*} \\
(64.06)\end{array}$ & $\begin{array}{r}-221.79 * * \\
(39.06)\end{array}$ & $\begin{array}{r}-236.23 \\
(129.15)\end{array}$ & $\begin{array}{r}29.02 \\
(59.83)\end{array}$ & $\begin{array}{r}28.92 \\
(59.94)\end{array}$ & $\begin{array}{r}31.14 \\
(59.32)\end{array}$ & $\begin{array}{r}32.18 \\
(62.40)\end{array}$ & $\begin{array}{r}58.54 \\
(70.05)\end{array}$ & $\begin{array}{r}42.98 \\
(64.00)\end{array}$ \\
\hline Quarterly real stock return & $\begin{array}{r}0.76 \\
(2.73)\end{array}$ & $\begin{array}{r}-5.74 \\
(3.22)\end{array}$ & $\begin{array}{r}-5.31 \\
(4.09)\end{array}$ & $\begin{array}{r}-12.26 \\
(7.49)\end{array}$ & $\begin{array}{r}1.15 \\
(3.02)\end{array}$ & $\begin{array}{r}1.21 \\
(3.08)\end{array}$ & $\begin{array}{r}0.86 \\
(2.75)\end{array}$ & $\begin{array}{r}1.09 \\
(3.01)\end{array}$ & $\begin{array}{r}0.34 \\
(2.60)\end{array}$ & $\begin{array}{r}1.46 \\
(2.89)\end{array}$ \\
\hline Quarterly GDP growth & $\begin{array}{r}-14.54 \\
(23.09) \\
\end{array}$ & $\begin{array}{r}-64.28 \\
(44.42) \\
\end{array}$ & $\begin{array}{r}-159.78^{* *} \\
(49.74) \\
\end{array}$ & $\begin{array}{r}-136.49 * * \\
(52.15) \\
\end{array}$ & $\begin{array}{r}-13.80 \\
(24.96) \\
\end{array}$ & $\begin{array}{r}-13.73 \\
(24.81) \\
\end{array}$ & $\begin{array}{r}-11.49 \\
(21.94) \\
\end{array}$ & $\begin{array}{r}-16.87 \\
(26.59) \\
\end{array}$ & $\begin{array}{r}-17.63 \\
(18.25) \\
\end{array}$ & $\begin{array}{r}4.92 \\
(22.64) \\
\end{array}$ \\
\hline $\mathrm{R}^{2}$ & 0.14 & 0.33 & 0.49 & 0.41 & 0.09 & 0.09 & 0.13 & 0.10 & $\begin{array}{r}0.22 \\
72 . \mathrm{Q} 1-\end{array}$ & 0.18 \\
\hline Period & Full & Full & Full & Full & Full & Full & Full & Full & 09.Q4 & Full \\
\hline
\end{tabular}

